
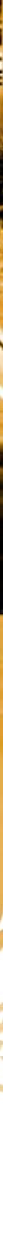

\title{
GUIDE TO PERFORMANCE-BASED ROAD MAINTENANCE CONTRACTS
}

APRIL 2018 

GUIDE TO PERFORMANCE-BASED
ROAD MAINTENANCE CONTRACTS

APRIL 2018 
(C) 2018 Asian Development Bank 6 ADB Avenue, Mandaluyong City, 1550 Metro Manila, Philippines

Tel +632632 4444; Fax +6326362444

www.adb.org

Some rights reserved. Published in 2018.

ISBN 978-92-9261-108-8 (print), 978-92-9261-109-5 (electronic)

Publication Stock No. TIM179099-2

DOI: http://dx.doi.org/10.22617/TIM179099-2

The views expressed in this publication are those of the authors and do not necessarily reflect the views and policies of the Asian Development Bank (ADB) or its Board of Governors or the governments they represent.

ADB does not guarantee the accuracy of the data included in this publication and accepts no responsibility for any consequence of their use. The mention of specific companies or products of manufacturers does not imply that they are endorsed or recommended by ADB in preference to others of a similar nature that are not mentioned.

By making any designation of or reference to a particular territory or geographic area, or by using the term "country" in this document, $A D B$ does not intend to make any judgments as to the legal or other status of any territory or area.

This work is available under the Creative Commons Attribution 3.0 IGO license (CC BY 3.0 IGO)

https://creativecommons.org/licenses/by/3.o/igo/. By using the content of this publication, you agree to be bound by the terms of this license. For attribution, translations, adaptations, and permissions, please read the provisions and terms of use at https://www.adb.org/terms-use\#openaccess.

This CC license does not apply to non-ADB copyright materials in this publication. If the material is attributed to another source, please contact the copyright owner or publisher of that source for permission to reproduce it. $\mathrm{ADB}$ cannot be held liable for any claims that arise as a result of your use of the material.

Please contact pubsmarketing@adb.org if you have questions or comments with respect to content, or if you wish to obtain copyright permission for your intended use that does not fall within these terms, or for permission to use the ADB logo.

Notes:

In this publication, "\$” refers to US dollars.

ADB recognizes "America" as the United States.

Corrigenda to ADB publications may be found at http://www.adb.org/publications/corrigenda.

Cover photos: Road maintenance and rehabilitation projects have resulted in the improved efficiency and safety of road transport links in Kazakhstan. Cover photo composite shows work done to upgrade road networks in Kazakhstan, including the Almaty-Bishkek corridor and the Taraz-Merke highway (photos by lgor Burgadinov/ADB). 


\section{Contents}

Tables, Figures, and Boxes

Abbreviations

Glossary

vii

Acknowledgments

Executive Summary

Objectives and Purpose

1. Introduction

1.1 What Are Performance-Based Road Maintenance Contracts?

1.2 Brief History of Performance-Based Road Maintenance Contracts

1.3 Advantages and Disadvantages

2. Basic Concepts of Performance-Based Road Maintenance Contracts

2.1 Types of Performance-Based Road Maintenance Contracts and Their Scope 5

2.2 Performance Levels

2.3 Payment and Incentive Systems

2.4 Performance Monitoring

2.5 Risks and Risk Mitigation

3. Implementation Experiences

3.1 Developed Countries

3.2 Developing and Transitional Countries

3.3 Central Asia Regional Economic Cooperation Countries

5. Performance-Based Road Maintenance Contracts Implementation Strategy in CAREC Member Countries

5.1 Create an Enabling Environment and Meet Preconditions

5.2 Design a Performance-Based Road Maintenance Contract Well 
6. Recommended Options for Pilot Performance-Based Road Maintenance Contracts in CAREC Member Countries

6.1 Option 1: Routine Maintenance for 3 to 4 Years for 100-150 km of Roads

6.2 Option 2: Routine and Periodic Maintenance for 5 to 6 Years for $150-200 \mathrm{~km}$ of Roads

6.3 Option 3: Routine and Periodic Maintenance for up to 10 Years for 700-1,000 km of Roads 


\section{Tables, Figures, and Boxes}

Tables

1 Reported Savings of Performance-Based Road Maintenance Contracts against Conventional Unit Price Contracts 2

2 Example of Performance Levels for Performance-Based Road Maintenance Contracts 10

3 Relationship between Traffic Volume, Performance Levels and Response Times for Performance-Based Road Maintenance Contracts 10

4 Examples of Payment Reductions in Performance-Based Road Management Contracts for Noncompliances with Performance Levels

$5 \quad$ Risk Distribution and Mitigation between Client and Contractor in Performance-Based Road Maintenance Contracts 14

6 Annual Routine Maintenance Cost of Roads in Tajikistan $(\$ / \mathrm{km})$

7 Performance Monitoring Compliance Rating in Tajikistan 25

8 Selection Criteria Used to Identify Pilot Site for Performance-Based Road Maintenance Contract in Indonesia

9 Qualifications of Key Personnel 35

10 Evaluation Criteria and Weights Applied for the Award of a Performance Contract in Washington, DC 36

A2 Framework for Assessing the Capacity of the Government, Contractors, and Consultants in Performance-Based Road Maintenance Contracts 51

Figures

1 Potential Scope of Works and Services of Performance-Based Road Maintenance Contracts 6

2 Relationship between Contract Scope, Complexity, and Duration in Performance-Based Road Maintenance Contracts

3 Relationship of Required Contractor's Skills as a Function of the Duration of Performance-Based Road Maintenance Contracts 8

4 Contractual Relationship between Client, Contractors, and Supervision Consultants for Hybrid Type Performance-Based Road Maintenance Contracts 9

$5 \quad$ Risk Sharing for Different Types of Road Maintenance Contracts 13

6 Complexity and Duration of Selected Performance-Based Road Maintenance Contracts 16

7 Contracts Used for Network Maintenance Management in New Zealand 18

8 Workforce Reduction in the Estonian Road Administration as a Result of the Adoption of Performance-Based Road Maintenance Contracts 20

9 Comparison of Winter Maintenance Unit Costs for Pilot Projects in Serbia against Costs from Central Serbia

1 Case Study: Reducing Road Maintenance Costs per Kilometer through Competition and the Introduction of Performance-based Road Maintenance Contracts in New South Wales 3

2 Importance of Timely Road Maintenance-Rule of Thumb 


\section{Abbreviations}

ADB Asian Development Bank

CAREC Central Asia Regional Economic Cooperation

CREMA Contrato de Rehabilitación y Mantenimiento (Road Rehabilitation and Maintenance Contract)

DPWH Department of Public Works and Highways

ERA Estonian Road Administration

IFI international financial institution

ISO International Organization for Standardization

MIS management information system

MOPW Ministry of Public Works

MPC mobile personal computer

OPRC Output-and Performance-Based Road Contract

PBC Performance-Based Road Maintenance Contract

PMMR Performance-Based Management and Maintenance of Roads

PMU performance management unit

PSRMC Performance Specified Road Maintenance Contract

RAM Road Asset Management

RMC Rehabilitation and Maintenance Contract

RMU Road Maintenance Unit

RTA Roads and Traffic Authority New South Wales

US United States

\section{Weights and Measures}

$\begin{array}{ll}\mathrm{cm} & \text { centimeter } \\ \mathrm{km} & \text { kilometer } \\ \mathrm{m} & \text { meter } \\ \mathrm{m}^{3} & \text { cubic meter } \\ \mathrm{mm} & \text { millimeter } \\ \$ / \mathrm{km} & \text { dollar per kilometer }\end{array}$




\section{Glossary}

Emergency Works

Improvements

Input Contract

Outcome Contract

Output Contract

Performance Levels

Periodic Maintenance

Program of Performance

Road Organization

Routine Maintenance
Necessary and sufficient activities to reinstate road assets and reconstruct their structure or right of way when they are strip damaged as a result of natural phenomena such as strong storms, flooding, earthquakes and avalanches

Activities to improve the functional performance of road assets, e.g., widening of the road, or providing additional assets such as weighbridges

A contract where payments are made on the amount of resources consumed, e.g., $\$ / \mathrm{m}^{3}$ of material, $\$ / \mathrm{hr}$ for labor or equipment

A contract where payments are made based on the provision of services and the maintenance of the quality or performance levels of the assets over the entire contract period. The contractor takes the risks on the quantity and quality of resources of the works and services.

A contract where payments are made on the basis of outputs, e.g., $\$ / \mathrm{km}$ of resurfacing. The contractor takes the risk on the resources involved and the quality of works and services.

Quality criteria that define the minimum condition of an asset, e.g., Potholes should not be greater than $10 \mathrm{~cm}$ in any direction

\section{See Resurfacing}

Management services that cover work program, operational plans, quality assurance plan, health and safety management plan, environmental management plan, risk management plan, emergency procedures and contingency plan, traffic management plan and information management plan

An organization in charge of the management and operation of road assets (i.e., Department of Public Works, Road Administration, Road Agency, etc.)

Activities, normally reactive, necessary to restore the conditions of road assets such as repair of potholes, sealing of cracks, repairing and cleaning of road signs, cleaning of drains, or grass cutting 
Rehabilitation

Resurfacing

Service Levels

Winter Maintenance

Winter Services
Reinstatement of the carrying capacity of pavement layers

Restoring the wearing course of a paved surfaces or re-gravelling of gravel surfaces See Performance Levels

Activities to keep road assets passable and safe in winter conditions

See Winter Maintenance 


\section{Acknowledgments}

The production of this guide has been administered and managed by the CAREC Secretariat at the Asian Development Bank (ADB). The secretariat team supporting Central Asia Regional Economic Cooperation (CAREC) road asset management work includes Ko Sakamoto, Ari Kalliokoski, Oleg Samukhin, Pilar Sahilan, and Debbie Gundaya of the Central and West Asia Department. This guide was written by Gunter Zietlow.

Invaluable inputs and data to this guide were contributed by ADB transport staff and the Road Sector Focal Points from each of the CAREC countries. 


\section{Executive Summary}

1. Road Asset Management (RAM) ${ }^{1}$ or road maintenance is one of the top priorities of the Central Asia Regional Economic Cooperation (CAREC) Transport and Trade Facilitation Strategy 2020 (TTFS 2020). Performance-based road maintenance contracts (PBC) are an essential element of RAM and their implementation contributes to improving the effectiveness and efficiency of the maintenance of road networks. Well-designed PBCs keep roads in predefined good condition at relatively low cost. Long-term PBCs, often referred to as Road Asset Management Contracts, require sound road asset management tools.

2. This guide is addressed to high-level policy makers, as well as technical staff in CAREC member countries, staff of the Asian Development Bank, and other development partners involved in the road sector.

3. The objective of this guide is to assist CAREC member countries to better understand the concept of PBCs, and serve as guidance on the implementation of such contracts. It describes different delivery modes of road maintenance, and gives a brief history of PBCs, as well as their advantages and disadvantages. It also defines various types of PBCs and their variable elements (e.g., scope, duration, extension, performance levels, payment and incentive systems, performance monitoring, and risks and risk mitigation). This guide focuses on road maintenance and does not cover other public-private partnership road delivery models such as design, build, finance, operate, and maintenance models or any of its variations, e.g., design-build, design-build-operate, design-buildfinance-operate, and design-build-operate-maintain.
4. This guide also discusses the implementation of some PBCs in developed, as well as developing and transitional countries, including CAREC countries, to see what has worked and what has not. From the developed countries, PBCs in Canada, Estonia, New Zealand, and the United States are considered. Insights from developing and transitional countries are taken from Argentina, Indonesia, Malaysia, Serbia, and Uruguay. Among the CAREC countries, examples are taken from Afghanistan, Georgia, and Tajikistan.

5. Lessons learned from implementing PBCs include the following:

- PBCs deliver good value for money and can better guarantee sufficient funding for road maintenance and improved road conditions to help reduce road user cost and improve road safety on a sustainable basis.

- PBCs can help save substantial amounts of road rehabilitation and reconstruction work. As a rule of thumb, each dollar spent in time on routine maintenance can save $\$ 3-\$ 5$ on future necessary rehabilitation or reconstruction works (in constant prices).

- Successful implementation of PBCs requires (i) an adequate road asset management system; (ii) strong commitment and support by key decision makers, particularly from the ministry of finance, the ministry in charge of roads, and the road organization; (iii) genuine engagement from road organization staff; and (iv) sufficient capacity from all stakeholders, including staff from the road organization, contractors, and consultants.

Road asset management is a strategic and systematic process of design and implementation of a road sector policy, and management of road sector institutions. It includes financing, managing, planning, maintaining, upgrading, expanding, and operating road, bridge, and road-side assets throughout their life cycle. This process uses financial, engineering, economic, and environmental principles combined with sound business practices, for effective and efficient resource use and allocation to provide services that meet the public's expectations. 
6. This guide outlines a strategy on how CAREC member countries can use PBCs to their advantage. It discusses how to create an enabling environment, and identifies preconditions that will enhance successful implementation. It considers approaches on how to design, procure, and implement PBCs effectively.

7. In relation to designing PBCs, this guide considers the (i) required technical studies, (ii) design of tender documents, (iii) data to be supplied to tenderers, and (iv) supervision arrangements.

8. For procurement, this guide discusses the (i) prequalification of contractors; (ii) organization of pre-bid seminars for prequalified contractors; (iii) bid evaluation; and (iv) preparation of tender documents for supervising or coaching and training consultants, and their respective qualification criteria.

9. For implementation, this guide discusses (i) the conduct of coaching and training of client and contractor stakeholders, and (ii) the establishment of adequate monitoring and evaluation processes.
10. This guide suggests three practical options for CAREC member countries to start implementing pilot PBCs:

- Option 1: PBC for routine maintenance, including winter services for 3-4 years for 100-150 kilometers $(\mathrm{km})$ of paved roads;

- Option 2: PBC for routine and periodic maintenance, including winter services for 5-6 years for $150-250 \mathrm{~km}$ of paved roads;

- Option 3: PBC for routine and periodic maintenance for up to 10 years for an extended paved road network for $700-1,000 \mathrm{~km}$.

11. Each option is discussed with regard to suitable road conditions, scope of works and services, payments, service levels, project delivery, and contract supervision.

12. Finally, this guide discusses the role of international financial institutions in supporting the implementation of PBCs in CAREC countries. 


\section{Objectives and Purpose}

1. The Transport and Trade Facilitation Strategy 2020 (TTFS 2020), endorsed at the 12th Central Asia Regional Economic Cooperation (CAREC) Ministerial Conference on 23-24 October 2013 in Kazakhstan, highlighted three operational priorities to improve the region's competitiveness and expand trade among CAREC economies and with the rest of the world. These are the (i) development of a multimodal corridor network, (ii) improvement of trade and border-crossing services, and (iii) improvement of operational and institutional effectiveness.

2. Road asset management (RAM) or road maintenance is a key issue under the third operational priority to improve operational and institutional effectiveness. Many CAREC countries continue to face challenges in meeting of the required financial and technical requirements necessary to maintain their road networks. A key feature of a RAM program is about knowing what is needed over the long term in order to set targets and budgets, and ensure performance of the transport network. Implementing a RAM is an organization-wide activity, requiring a diverse skill set. There are clear guidelines and standards to follow, and the implementation of a RAM on a permanent basis requires strong leadership.

3. Closely related to effective RAM is the use of performance-based road maintenance contracts (PBCs). It is now generally accepted that PBCs, if structured and implemented properly, may provide an entry point for the development of prerequisite conditions for an effective RAM system. The 14th Transport Sector Coordinating
Committee Meeting held in April 2015 reconfirmed the keen interest of CAREC member countries to implement PBCs.

4. CAREC countries rely on development assistance so that they can adopt PBCs. However, the development community defines the scope and implementing arrangements for PBCs differently, which often results in confusion or worse, in the inappropriate or ineffective application of the concept, particularly when local conditions are not taken into account when PBCs are designed and introduced.

5. This guide is intended to serve CAREC member countries in better understanding the concept of PBCs and serve as guidance for the implementation of such contracts. This guide concentrates on road maintenance and does not cover other public-private partnership road delivery models, such as design, build, finance, operate, and maintenance models or any of its variations (e.g., design-build, design-build-operate, design-buildfinance-operate, and design-build-operate-maintain).

6. This guide is addressed to high-level policy makers as well as technical staff in CAREC member countries, Asian Development Bank staff, and other development partners involved in the road sector.

7. It is meant to be a living document that may be updated from time to time and reflects the collective knowledge of CAREC member countries in applying PBCs in their road maintenance and operations. 


\section{Introduction}

\subsection{What Are Performance-Based Road Maintenance Contracts?}

1. Road maintenance has traditionally been the realm of public road organizations. Many countries in the Central Asia Regional Economic Cooperation (CAREC) region are still performing road maintenance in-house, especially routine road maintenance.

2. However, there is now a global trend for such work to be contracted out to the private sector. The main reason for shifting to such contracts is to improve efficiency. Provided that there are qualified road maintenance contractors with adequate competition, cost savings of between 30\% to $50 \%$ have been realized in other regions (Frost and Lithgow 1996; and Zietlow 2015). Thus, some countries have turned to contractors to deliver road maintenance.

3. There are three types of road maintenance contracts:

- Method based or conventional contracts with unit rates for work items and payments based on quantities of measured quantities of works completed, which is the traditional way of contracting out road maintenance;

- Performance-based road maintenance contracts (PBC) with performance levels defined for each road asset or service provided under the contract with fixed payments if performance levels are met, or payment reductions for noncompliance;

- Mixed or hybrid PBCs that contain elements of both contract types.
4. Most PBCs worldwide are mixed or hybrid PBCs, where most works and services are performance based. Emergency, major rehabilitation and improvement works are often paid on the basis of unit prices and quantities of works completed. Some PBCs contain outputbased work items such as specified improvement or rehabilitation works (e.g., a number of kilometers $(\mathrm{km})$ of a defined overlay per year), paid on a lump sum basis. These contracts are also referred to as Output- and Performance (Outcome)-Based Contracts. ${ }^{2}$ There is no common terminology for PBCs. Each country differs in the terminology that they use, ${ }^{3}$ as well as in the scope of the work, method of payments, duration of the contract, and management arrangements.

5. What all PBCs have in common is that the contractor needs to maintain the road assets in predefined good conditions or service levels during the entire contract period. Payments are based on how well the contractor manages to comply with the performance or service levels obligations defined in the contract, and not on the amount of works and services executed. It is up to the contractor how to achieve this. Therefore, work selection, design, and delivery are all the contractor's responsibility. Hence, the choice and application of technology and the pursuit of innovative materials, processes and management are all up to the contractor as long as there is compliance with the relevant laws and regulations. Compared to conventional contract arrangements where the client determines work selection, design and delivery, PBCs allocate a higher risk to the contractor. At the same time, it opens opportunities for increased profit margins as improved efficiencies and effectiveness of design, process, technology or

The World Bank uses the term output and performance-based road contract (OPRC). Some countries like New Zealand use the term output instead of performance.

3 For example: Performance contract (Western Australia), asset management contract (United States); performance-specified maintenance contract (Australia, New Zealand); contract for rehabilitation and maintenance (Argentina, Brazil); area maintenance contract (Finland; Ontario, Canada); managing agent contract (United Kingdom); output and performance road contract (World Bank). 
management can reduce the cost of achieving the specified service levels.

\subsection{Brief History of Performance-Based Road Maintenance Contracts}

6. The development of PBCs started in the late 1980s and early 1990s. In 1988, British Columbia in Canada started to contract out road maintenance to the private sector by introducing some performance levels for routine maintenance. Two years later, Argentina contracted out almost half of its national roads using performance levels for maintenance works and services including periodic maintenance and spot rehabilitations, with a penalty system for failures to meet response times for rectifying deficiencies.

7. During the 1990s, many countries in Latin America such as Brazil, Chile, Peru, and Uruguay started their first PBC pilot projects. At the same time, PBCs developed in Australia and New Zealand as well as in Denmark, Estonia, Finland, and the United States (US). Many other countries followed after the year 2000.

8. In some countries, such as Argentina and Canada, PBCs have almost entirely replaced the traditional way of contracting out road maintenance and have had a chance to evaluate the value-added benefits of using PBCs. The rapid adoption of PBCs worldwide indicates that such contracts deliver better value for money than conventional contracts and can guarantee good road conditions at the same time. It is expected that this trend will continue and PBCs will eventually replace the traditional way of contracting out road maintenance.

\subsection{Advantages and Disadvantages}

9. The main reason why developed countries have switched from conventional contracting out road maintenance to PBCs is the potential for cost savings. Reported savings are typically between 15\% and 30\% when compared with the same scope of works undertaken by conventional unit price contracts. Table 1 illustrates reported savings in select countries.
Table 1: Reported Savings of Performance-Based Road Maintenance Contracts against Conventional Unit Price Contracts

\begin{tabular}{|l|c|}
\hline Country & $\begin{array}{c}\text { Reported Savings against } \\
\text { Conventional Unit Price } \\
\text { Contracts }\end{array}$ \\
\hline Australia & $10 \%-40 \%$ \\
\hline Brazil & $15 \%-35 \%$ \\
\hline Canada & About 20\% \\
\hline Estonia & $20 \%-40 \%$ \\
\hline Finland & $18 \%$ \\
\hline The Netherlands & $30 \%-40 \%$ \\
\hline New Zealand & $15 \%-38 \%$ \\
\hline United States & $10 \%-15 \%$ \\
\hline
\end{tabular}

Source: P. Pakkala et al. 2007.

10. Generally, cost reductions were largest when contractors faced strong competition and have gained experiences with PBCs. Since PBCs are fixed price contracts, contractors have an incentive to maintain the contracted service levels at the lowest cost possible. The longer the contract duration, the higher the incentive. Besides competition, modern management and work procedures, increased labor productivity, total life cycle costing, just-in-time maintenance, and better use of latest technologies have driven down costs. A welldocumented case for demonstrating the importance of good competition in driving down costs is illustrated in Box 1. A word of caution however: when there is a lack of competition, the expected savings might not be realized.

11. For developing countries, the main driving force to introduce $\mathrm{PBCs}$ is to secure sufficient long-term financing for road maintenance and guarantee better road conditions. The experiences of Argentina, Malaysia, and Uruguay provide good examples of this.

12. In 2000, Malaysia introduced area-wide PBCs with a 15 -year term on all its national roads and was successful in securing sufficient road maintenance funds during the entire contract period. Argentina and Uruguay were similarly successful in their respective efforts. 


\section{Box 1: Case Study: Reducing Road Maintenance Costs per Kilometer through Competition and the Introduction of Performance-Based Road Maintenance Contracts in New South Wales}

In 1990, the Roads and Traffic Authority (RTA) of New South Wales initiated a pilot road maintenance contract project in the Sydney region. The objectives of the pilot were to establish the feasibility of contracting road maintenance and to measure differences in cost, quality, and responsiveness between a private contractor and the RTA workforce. RTA choose two road sections each measuring 100 kilometers $(\mathrm{km})$, and with similar road conditions. One section was given to an RTA team to maintain while the other was contracted to the private sector for 2 years and retendered for two additional 2-year terms. Both the RTA team and the private contractor were supervised by a consultant and were subject to the same service levels.

The box figure below illustrates how good competition can reduce maintenance costs over time. After the third tender round, maintenance costs had been reduced by $48 \%$. In addition, the 5-year performance contract on urban roads in Sydney produced even more savings due to increased competition, extended road network and longer contract period.

This example demonstrates that (i) shifting from in-house works to contracting out based on conventional maintenance contracts with unit prices produces significant savings, and that (ii) further savings are possible by introducing PBCs. In this case, the total savings amounted to more than $60 \%$ compared to the cost of delivering maintenance services in-house.

\section{Box Figure: Maintenance Costs Over Time (\% 1991 rates)}

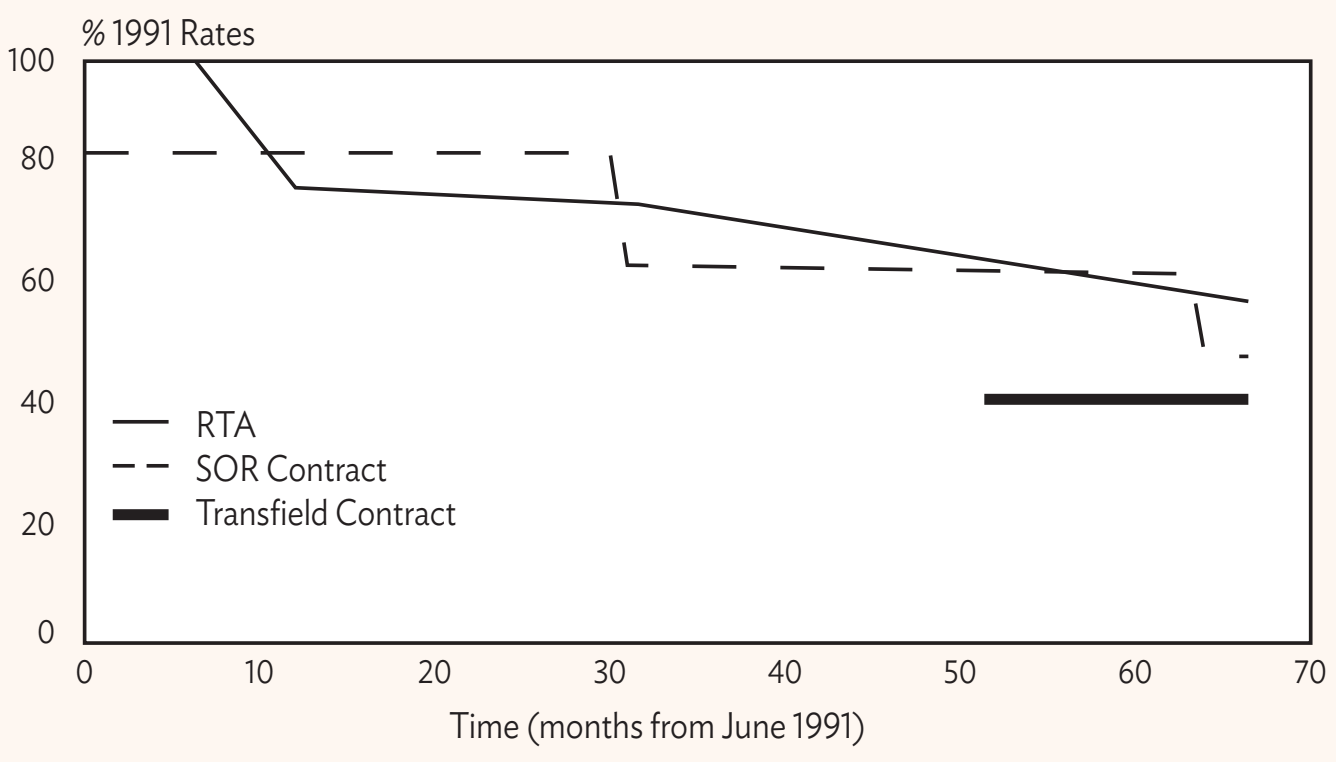

RTA $=$ Roads and Traffic Authority, SOR = schedule of rates

Source: M. Frost and C. Lithgow. 1996.

Even during the 2002 economic crisis, both countries were able to honor their commitments towards all their respective PBCs.

13. Besides the potential to reduce road maintenance costs and secure long-term financing, PBCs help in the following manner:

\section{Road Agencies}

- Savings on rehabilitation costs, since roads in good condition avoid rehabilitation

- Safeguards against cost overruns from frequent claims and contract amendments to increase quantities of work 
- Reduction in the workload of staff

- Improvement in the quality of works

- Improvement in control and enforcement of performance levels

- Improvement in road safety

\section{Road Users}

- Savings on road user costs

- Better and safer roads with consistent conditions

\section{Contractors and Consultants}

- Guaranteed consistent workload over longer periods
- Improved the potential for increased margins

- Developing excellent opportunities for business growth

14. The enormous savings offered by reducing or delaying road rehabilitation or reconstruction ${ }^{4}$ costs, and reducing road vehicle operating costs, surpass by far the costs of a disciplined maintenance regime (Box 2).

15. The above-mentioned benefits provide compelling justification to implement long-term PBCs. This is especially true for developing countries with a history of insufficient road maintenance funding and relatively poor road conditions.

\section{Box 2: Importance of Timely Road Maintenance-Rule of Thumb}

When roads are in poor condition, every dollar not spent on road maintenance will cost the following:

- For road users, $\$ 4-\$ 5$ in additional vehicle operating costs, travel time losses, and additional accidents

- For road organizations, $\$ 4-\$ 6$ in reconstruction and rehabilitation costs

Sources:

S. Burningham and N. Stankevich. 2005; and Smart Growth America. 2014.

4 Reconstruction is defined as "renewing the entire road structure," while rehabilitation refers to the "replacement of the base course and the road surface (surface course, binder course, and asphalt course)." 


\section{Basic Concepts of Performance-Based Road Maintenance Contracts}

\subsection{Types of Performance-Based Road Maintenance Contracts and Their Scope}

16. PBCs used by developing and transitional countries usually fall within one of the following categories:

- Output- and Performance-Based Road Contract (OPRC) or Rehabilitation and Maintenance Contract (RMC). These are PBCs that require major capital works (initial rehabilitation and periodic works) comprising more than $30 \%$ of the total contract price, besides routine maintenance and winter maintenance (where required). These are the most common type of PBCs used by developing and transitional countries due to the prevalence of poor road conditions.

- Network Management PBCs, Performance Specified Road Maintenance Contract (PSRMC), or Performance-based Management and Maintenance of Roads (PMMR). These $\mathrm{PBC}$ s require no or little initial works to bring roads to the required service levels, apart from routine maintenance and winter maintenance (where required), and periodic maintenance.

- Service Level Maintenance Contract. PBCs for routine and winter maintenance, if required.

- Microenterprise PBC. Simple PBCs for routine maintenance on paved roads, mainly applied to provincial and community based roads. ${ }^{5}$
- Community-Based Maintenance Contract. Simple PBCs for routine maintenance on unpaved roads.

17. PBCs are being applied on national, provincial, local and urban paved or unpaved roads and vary in scope and duration. The different types of PBCs mainly used in developing countries are discussed in Appendix 1.

18. The potential scope of works and services that can be covered under PBCs are illustrated in Figure 1.

19. The scope of works and services of PBCs may cover only routine maintenance or one or several of the other works and services involved in road network management and operation, winter services, periodic maintenance, and emergency, rehabilitation, and improvement works. At the same time, works and services may cover some or all road assets, which typically include

- paved areas of roads, parking areas, lay-bys, footways, and the like;

- unpaved shoulders, medians, and verges;

- signs, road markings, and road safety furniture like guard rails and delineators;

- road lighting and associated facilities;

- bridges, tunnels, culverts, earth retaining structures, and other structures;

- drainage structures like drainage ditches, pipes, manholes, and related items;

- slopes of cuttings and embankments; 
Figure 1: Potential Scope of Works and Services of Performance-Based Road Maintenance Contracts

\section{Road Network}

Management and Operation

Routine/Recurement

Maintenance
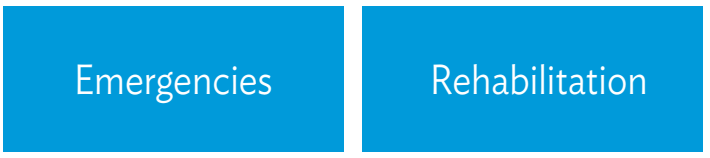

Periodic

Maintenance

Source: G. Zietlow. 2009.

- landscaped areas;

- miscellaneous facilities such as weighbridges, bus shelters, rest areas, weather stations, and the like.

20. Road Network Management and Operation covers the following:

- Management Services inclusive of

- management information system (MIS)

- contractor's works program

- reporting

- quality assurance system

- health and safety management plans

- environmental management plan

- emergency procedures and contingency plan

- traffic management plan

- inventory database management

- inspections

- Operation of weather stations

- Traffic management

- Road patrols

- Emergency telephones and road side assistance

- Operation of weigh scales
21. To minimize interference with other contractors on the same road, or disputes as to responsibility, it is recommended to include as many works and services as possible under one PBC on a specific road.

22. The duration of PBCs varies from 1 to 30 years. As a rule of thumb, contract duration should cover at least one periodic maintenance cycle. This is $4-5$ years for unpaved roads and 8-10 years for paved roads. PBCs that last 1-4 years are common when road organizations begin to shift from conventional contracts to $\mathrm{PBCs}^{6}$ to gain experiences with this new type of contract. PBCs that are 4-10 years normally cover routine and periodic maintenance, winter services (where required), emergency works, and sometimes spot rehabilitation and improvement works.

23. Contracts for more than 10 years normally cover the entire scope of works and services and often new construction works as well. Such contracts are common for road concessions with or without tolls. The longer the $\mathrm{PBC}$ contract period, the greater the complexity, therefore requiring increased contractor asset management skills. Figure 2 illustrates the relationship between scope, contract complexity, and contract duration.

6 For example, Finland and Estonia started with 1-year routine maintenance PBCs, gradually increasing the duration and scope to 8 years, while Uruguay started with 4-year PBCs. 


\section{Figure 2: Relationship between Contract Scope, Complexity, and Duration} in Performance-Based Road Maintenance Contracts

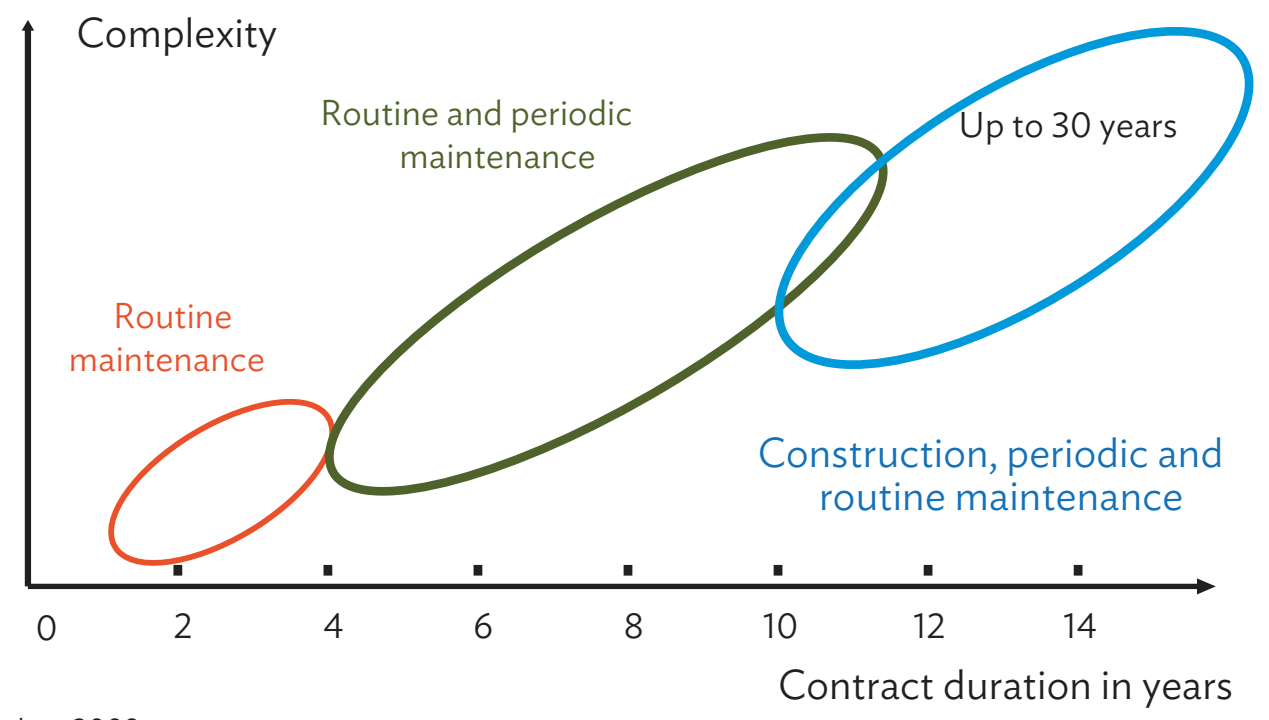

Source: G. Zietlow. 2009.

24. In developing countries, where road conditions may have deteriorated to such an extent that major rehabilitation works are required to bring up the roads to maintainable conditions, major rehabilitation works are often part of PBC contract scope. Such contracts normally range from 3 to 5 years. ${ }^{7}$ Since initial rehabilitation works often represent more than $50 \%$ of the contract amount, such contracts tend to attract contractors who are more interested in the capital works rather than the maintenance works and tend to give little attention to PBC components. Since many developing countries are faced with the same situation of having roads that cannot be maintained by maintenance works only, it is recommended that such rehabilitation and maintenance PBCs be extended to at least 8 years. This will incentivize contractors to pay more attention to the PBC components and to deliver highquality capital works.

25. The number of kilometers of roads covered by PBCs varies widely. Simple contracts that include only off road routine maintenance, commonly used in rural areas, cover between 20 and $50 \mathrm{~km}$. These contracts are also referred to as community based PBCs. ${ }^{8}$ Most other PBCs cover between 200 and $500 \mathrm{~km}$. Pilot PBCs tend to cover less kilometers. In exceptional cases, a PBC may cover as much as $7,000 \mathrm{~km}$ of roads, as in Malaysia.

26. $P B C$ s require a contractor with a specific skill set tailored to managing PBCs successfully. Instead of being told what to do and when and how, contractors need to develop capacity to plan their works and services to comply with predefined performance levels over the whole contract period. This requires certain skills whereby contractors can analyze the deterioration pattern of road assets by utilizing asset management systems, quality assurance management and more sophisticated management information systems. These skills are presently more likely to be found with consultants. The longer and more complex the PBC, the more contractors need such skills (see Figure 3). If contractors do not have such qualifications, they would have to acquire them, for example, by employing qualified consultants.

7 Three-year contracts are common in Brazil while Argentina started with 5-year rehabilitation and maintenance contracts, known as CREMA.

$8 \quad$ G. Zietlow. 2005; and ADB. 2011. 


\section{Figure 3: Relationship of Required Contractor's Skills as a Function of the Duration of Performance-Based Road Maintenance Contracts}

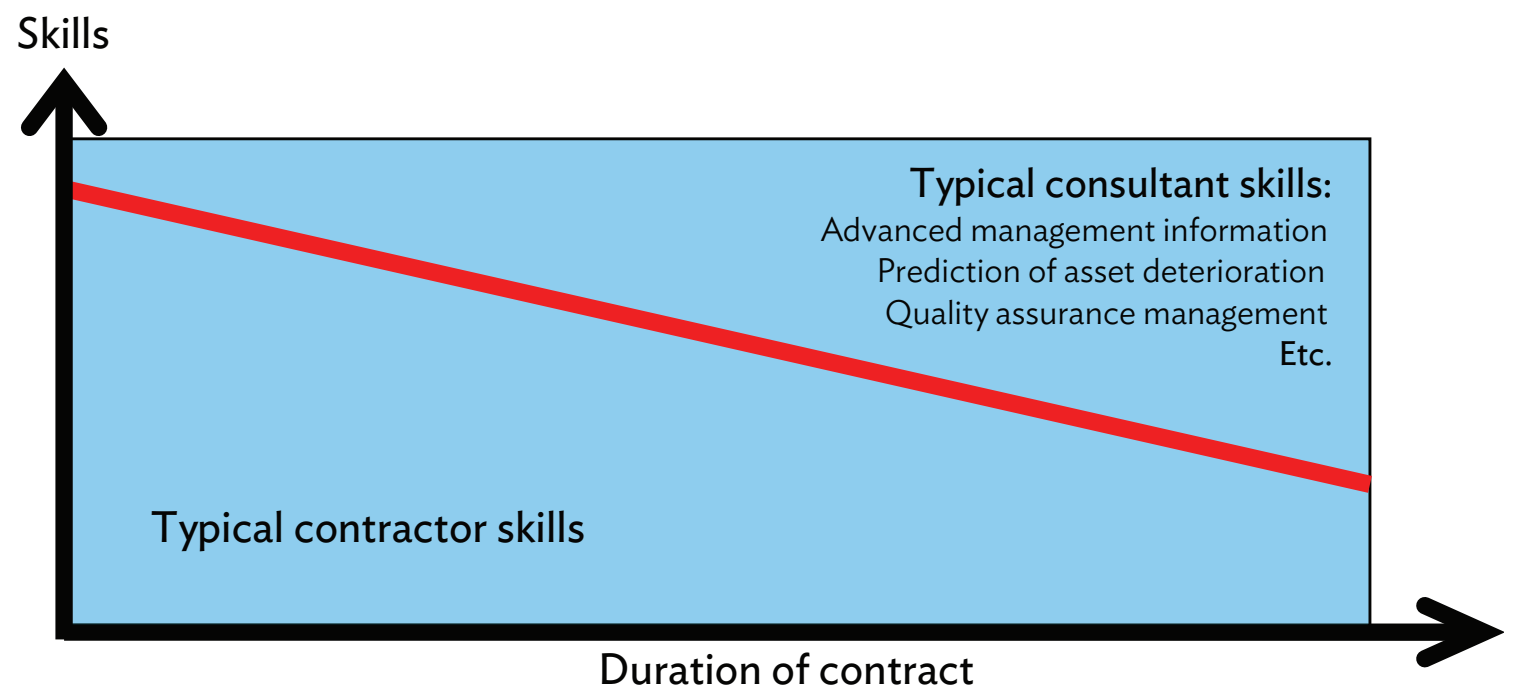

Source: G. Zietlow. 2015

27. PBCs require a different contractual relationship between client and contractor. In a PBC where all works and services are paid on performance the client concludes the contract with a performance audit, which can be conducted by the client or an external consultant or both. In a mixed or hybrid PBC, the client needs to supervise and certify admeasured works in addition to the audit functions. Figure 4 illustrates this new relationship between client, contractor and supervision consultant for hybrid type PBCs.

\subsection{Performance Levels}

28. Performance levels are minimum conditions of road, bridge, road side, and traffic assets that must be met by the contractor over the entire contract period and may cover other services such as winter services, the collection and management of asset inventory data, call-out and attendance to emergencies, and response to public requests, complaints, and feedback.

29. Performance levels are usually grouped into two categories (a) Management performance levels, which reflect the ability of the contractor to successfully manage the contract outputs, including the provision of timely reporting information to the client regarding

- contractor's works program

- quality assurance system

- $\quad$ health and safety management plans

- environmental management plan

- emergency procedures and contingency plan

- traffic management plan

- inventory database management

- inspections

- management information system, and

(b) Operational performance levels

- pavement condition

- $\quad$ road marking and pavement markers

- drainage system

- road signs

- vegetation control

- winter services (where applicable)

- incident response

- road patrol

- routine maintenance of bridges and structures 
Figure 4: Contractual Relationship between Client, Contractors, and Supervision Consultants for Hybrid Type Performance-Based Road Maintenance Contracts

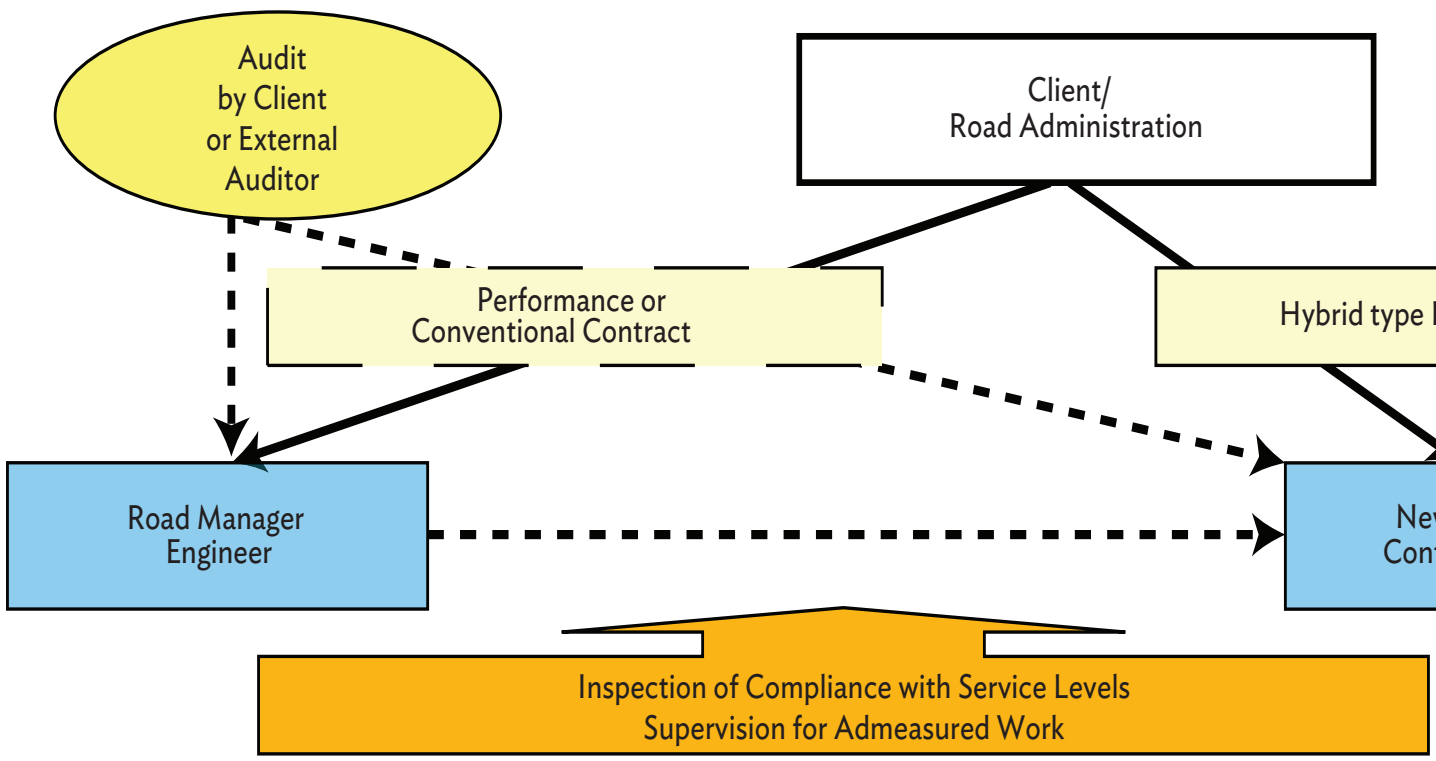

$\mathrm{PBC}=$ performance-based road maintenance contracts.

Source: G. Zietlow. 2011.

- roadside telephone and emergency services

- operation of weather stations

30. Operational performance levels need to satisfy three main objectives:

(a) to satisfy road users with respect to accessibility, comfort, travel speed and safety;

(b) to minimize total long term cost to the road organization and road users; and

(c) to minimize environmental impacts

31. Performance levels need to align with these objectives and be easily understood, clearly defined, objectively and easily measurable, affordable, low collection cost, and consistent with relevant laws and regulations.

32. The following example illustrates the relationship between objectives and performance levels:
- road safety: potholes should not be wider than $15 \mathrm{~cm}$ in diameter;

- preservation of road asset: cracks should not be wider than $3 \mathrm{~mm}$, obstruction of culverts should be less than $20 \%$ of its cross section;

- vehicle operating cost and comfort: Roughness in International Roughness Index (IRI) less than 3;

- travel time: calculated based upon an average speed greater than $50 \mathrm{~km} / \mathrm{hr}$.

33. Table 2 illustrates an example of performance levels.

34. To optimize total system cost, performance levels may differ from traffic levels on a road section. This is also true for response times, during which the contractor needs to rectify any noncompliance. An example that demonstrates the relationship between traffic volume, performance level, and response times is illustrated in Table 3. 
Table 2: Example of Performance Levels for Performance-Based Road Maintenance Contracts

\begin{tabular}{|c|c|}
\hline Item & Performance Level \\
\hline Potholes in pavements & $\begin{array}{l}\text { The permitted maximum dimension of any single pothole is [insert value, the suggested value is between } 0 \text { and } \\
40 \mathrm{~cm} \text { ]. } \\
\text { The permitted maximum number of accumulated potholes with an equivalent diameter greater than } 100 \mathrm{~mm} \text { in } \\
\text { any continuous } 1,000 \mathrm{~m} \text { section is [Insert value, suggested value is between } 0 \text { and } 10 \text { per km of road]. }\end{array}$ \\
\hline Patching & $\begin{array}{l}\text { Patches (i) shall be square or rectangular, (ii) shall be level with surrounding pavement, (iii) shall be made using } \\
\text { materials similar to those used for the surrounding pavement, and (iv) shall not have any cracks wider than } 3 \mathrm{~mm} \text {. }\end{array}$ \\
\hline Cracking in pavement & There should be no cracks wider than $3 \mathrm{~mm}$ wide. \\
\hline Multiple cracks in pavement & $\begin{array}{l}\text { For any } 50 \mathrm{~m} \text { section of the pavement, the cracked area cannot be more than } 10 \% \text { of the pavement surface. The } \\
\text { cracked area is measured by a rectangular parallel to the centerline of the pavement with a } 10 \mathrm{~cm} \text { distance between } \\
\text { any crack and any sideline of the rectangular. }\end{array}$ \\
\hline Rutting & $\begin{array}{l}\text { There should not be any ruts deeper than [insert value between } 20 \text { and } 40] \mathrm{mm} \text {. } \\
\text { Rutting of more than } 10 \mathrm{~mm} \text { should not be present in more than } 5 \% \text { of any of the road sections defined in the } \\
\text { contract. }\end{array}$ \\
\hline
\end{tabular}

$\mathrm{cm}=$ centimeter, $\mathrm{km}=$ kilometer, $\mathrm{m}=$ meter, $\mathrm{mm}=$ millimeter.

Source: World Bank. 2006.

Table 3: Relationship between Traffic Volume, Performance Levels and Response Times for Performance-Based Road Maintenance Contracts

\begin{tabular}{|c|c|c|c|c|}
\hline & Fair & Good & Very Good & Excellent \\
\hline Typical Traffic Volumes (vehicles/day) & $<250$ & $250-1,000$ & $1,001-5,000$ & $>5,000$ \\
\hline Potholes (maximum diameter of any single pothole) & $40 \mathrm{~cm}$ & $30 \mathrm{~cm}$ & $15 \mathrm{~cm}$ & $0 \mathrm{~cm}$ \\
\hline \multicolumn{5}{|l|}{$\begin{array}{l}\text { Potholes (maximum number in any } 1,000 \mathrm{~m} \text { with diameter } \\
\text { greater than } 10 \mathrm{~cm} \text { ) }\end{array}$} \\
\hline Patching (response time) & 28 days & 28 days & 14 days & 7 days \\
\hline $\begin{array}{l}\text { Cleanliness of the pavement surface and shoulders for safety } \\
\text { related matters (response time) }\end{array}$ & 10 hours & 8 hours & 6 hours & 3 hours \\
\hline
\end{tabular}

$\mathrm{cm}=$ centimeter, $\mathrm{km}=$ kilometer .

Source: World Bank. 2006.

35. Good examples for performance levels and response times can be found in sample bidding documents prepared by the World Bank and the Government of the State of Punjab, India. ${ }^{9}$

9 World Bank. 2006; and Government of India, State of Punjab, Public Works Department. 2011. 


\subsection{Payment and Incentive Systems}

36. In a PBC, the contractor receives lump sum payments, usually monthly, if services are delivered in compliance with the contract-defined performance levels. For any noncompliance, the contractor suffers payment reductions. Some other works and services might also be paid based on lump sums, like periodic maintenance, rehabilitation, or improvement works. These works will be paid on work progress or when the work is completed. Liquidated damages are applied for not completing these works on time. Emergency works are normally paid on unit prices as admeasured works. In exceptional cases, some routine maintenance activities are paid on unit prices if the contractor cannot realistically estimate the deterioration of the specific road asset, or the available funds do not allow for the full application of all performance levels for routine maintenance. ${ }^{10}$

37. Payment reductions are applied for noncompliance with performance levels. In the past, the term "penalties" was used, but it was not well received by contractors. In common law jurisdictions, penalties may be unenforceable. This led to the introduction of term payment reductions.

38. In some PBCs, bonus systems have been applied for exceeding certain benchmarks. For example, in the first PBC in Washington, DC in the US, the contractor could receive $100 \%$ payment if he was able to comply with $80 \%$ of the total score related to the overall performance, and additional payments for better performance.

39. The value of payment reductions should be high enough as to give the contractor sufficient incentive to comply. If the payment reductions are too low, contractors tend to be less compliant; if too high, contractors may apply a risk premium on their tender price. Therefore, great care should be used to determine appropriate payment reductions for each instance of noncompliance.

40. The noncompliance with each performance level results in a specific payment reduction. Payment reductions may be applied when, for example, a report is not submitted on time, or the average roughness of a road sections is more than specified, or a pothole exceeds the maximum diameter. Payment reductions are expressed as an amount in monetary terms or as percentages of the monthly lump sum per kilometer. Normally, payment reductions are applied when the client or his representative detects a noncompliance and additional payment reduction are applied for each time period the noncompliance is in effect. Additional payment reductions are made for not correcting the deficiency within a certain response time. Payment reductions might escalate if response times are repeatedly not met. For more details of how payment reductions are applied, refer to section 2.4 on Performance Monitoring. Examples of application of payment reductions are provided in Table 4.

41. Another payment approach can involve a scoring system. Each noncompliance is assigned a weight according to its importance and a corresponding score. At the end of the month, these scores are aggregated. If the total score is lower than a predefined threshold, the contractor receives $100 \%$ payment. If the total score is higher than the threshold, payments are reduced to a point where no payments will be made during that month. ${ }^{11}$

\subsection{Performance Monitoring}

42. PBCs require an effective and efficient performance monitoring and inspection system. This is mainly achieved by a self-control system by the contractor, and inspections or audits by the client, and supported road users.

43. To comply with performance levels, the contractor needs to establish adequate procedures implemented through a special unit with qualified staff. Some performance levels, like those which relate to road safety hazards, need to be controlled almost constantly. Others, such as road roughness or bridge inspections, require less frequent inspections. Daily patrols as well as an emergency call center are important elements of PBCs.

10 In South Africa, pothole patching was paid on unit prices, but the contractor needed to fix them within a certain response time. In its first pilot PBC, Croatia did not have a sufficient opportunity to comply with all performance levels and left some routine maintenance items to be paid on unit price basis.

11 This system is being used in the OPRC in Punjab. See Government of India, State of Punjab, Public Works Department. 2011. 

Table 4: Examples of Payment Reductions in Performance-Based Road Management Contracts
for Noncompliances with Performance Levels

\begin{tabular}{|l|l|l|l|}
\hline Criteria & \multicolumn{1}{|c|}{ Performance level } & \multicolumn{1}{c|}{$\begin{array}{c}\text { Payment reduction on first } \\
\text { inspection } \\
(\% \text { of monthly lump sum/km) }\end{array}$} & $\begin{array}{c}\text { Payment reduction on } \\
\text { subsequent inspections } \\
(\% \text { of monthly lump sum/ } \mathrm{km})\end{array}$ \\
\hline $\begin{array}{l}\text { Potholes on } \\
\text { carriage ways }\end{array}$ & $\begin{array}{l}\text { Potholes shall not be wider than } 10 \mathrm{~cm} \\
\text { in any direction }\end{array}$ & $\begin{array}{l}5 \% \text { for each } 1-\mathrm{km} \text { road section that } \\
\text { contains the pothole }\end{array}$ & $\begin{array}{c}15 \% \text { for each } 1-\mathrm{km} \text { section until pothole } \\
\text { is fixed }\end{array}$ \\
\hline Rutting & $\begin{array}{l}\text { Rut depth shall not exceed } 20 \mathrm{~mm} \text { for a } \\
\text { length of } 3 \mathrm{~m} \text { in any } 100 \mathrm{~m} \text { section }\end{array}$ & $\begin{array}{l}10 \% \text { applied to each } 100 \mathrm{~m} \text { section } \\
\text { which does not comply }\end{array}$ & $\begin{array}{l}20 \% \text { applied to each } 100 \mathrm{~m} \text { section } \\
\text { until the rutting is fixed }\end{array}$ \\
\hline Vertical Signage & $\begin{array}{l}\text { One or more traffic signs is absent, } \\
\text { destroyed, illegible, incorrectly placed } \\
\text { or nonfunctional }\end{array}$ & $5 \%$ & $10 \%$ until signs are replaced or fixed \\
\hline Vegetation & $\begin{array}{l}\text { The maximum vegetation height } \\
\text { measured anywhere in a } 100 \mathrm{~m} \text { section } \\
\text { is above the threshold value }\end{array}$ & $5 \%$ for each $100 \mathrm{~m}$ section & $\begin{array}{l}10 \% \text { for each } 100 \mathrm{~m} \text { section until } \\
\text { vegetation is trimmed to permissible } \\
\text { height }\end{array}$ \\
\hline
\end{tabular}

$\mathrm{cm}=$ centimeter, $\mathrm{km}=$ kilometer, $\mathrm{m}=$ meter, $\mathrm{mm}=$ millimeter.

Source: Author.

44. There are several methods used to monitor compliance. The most common ones are the following:

- At the end of each month, the contractor submits a compliance report to the client for payment and the client makes spot checks of the correctness of the report and makes adjustments, if necessary. On this basis, the payment reduction is calculated.

- At the end of each month, there is a joint inspection by the contractor and the client or his representative and all noncompliances are recorded and sanctioned by payment reductions. The client conducts follow up inspections to verify if the contractor has rectified the deficiency within the response time defined in the contract. If not, additional payment reductions are applied. In most cases, only a percentage of the roads included in the PBC are inspected monthly. Road sections are chosen by random selection. In very few cases, the entire road is inspected. This is applied to pilot projects with limited road length.

- The contractor records all noncompliances in an electronic, and preferably online, management information system, and is granted response times to rectify deficiencies. If the contractor does not rectify the deficiencies in time, payment reductions automatically apply and will substantially increase for such subsequent periods where the deficiency is not corrected. The client inspects the road at random selection. If the client detects any noncompliance, the client will then check whether the noncompliance was entered into the management information system. If not, the contractor will have to pay a penalty in the form of higher payment reductions for failing to detect the noncompliance. This system is being used in Ukraine.

\subsection{Risks and Risk Mitigation}

45. Risk management plays a bigger role in PBCs than in conventional contracts. In PBCs, significant risks are transferred from the road organization to the contractors. Generally, the longer the contract, the more risk the contractor must assume, as illustrated in Figure 5.

46. PBCs require equitable sharing of risks between client and contractor. Usually, contractors are willing to take some of the risks, provided that the nature of the risks relate to their expertise so that they will be able to 
Figure 5: Risk Sharing for Different Types of Road Maintenance Contracts

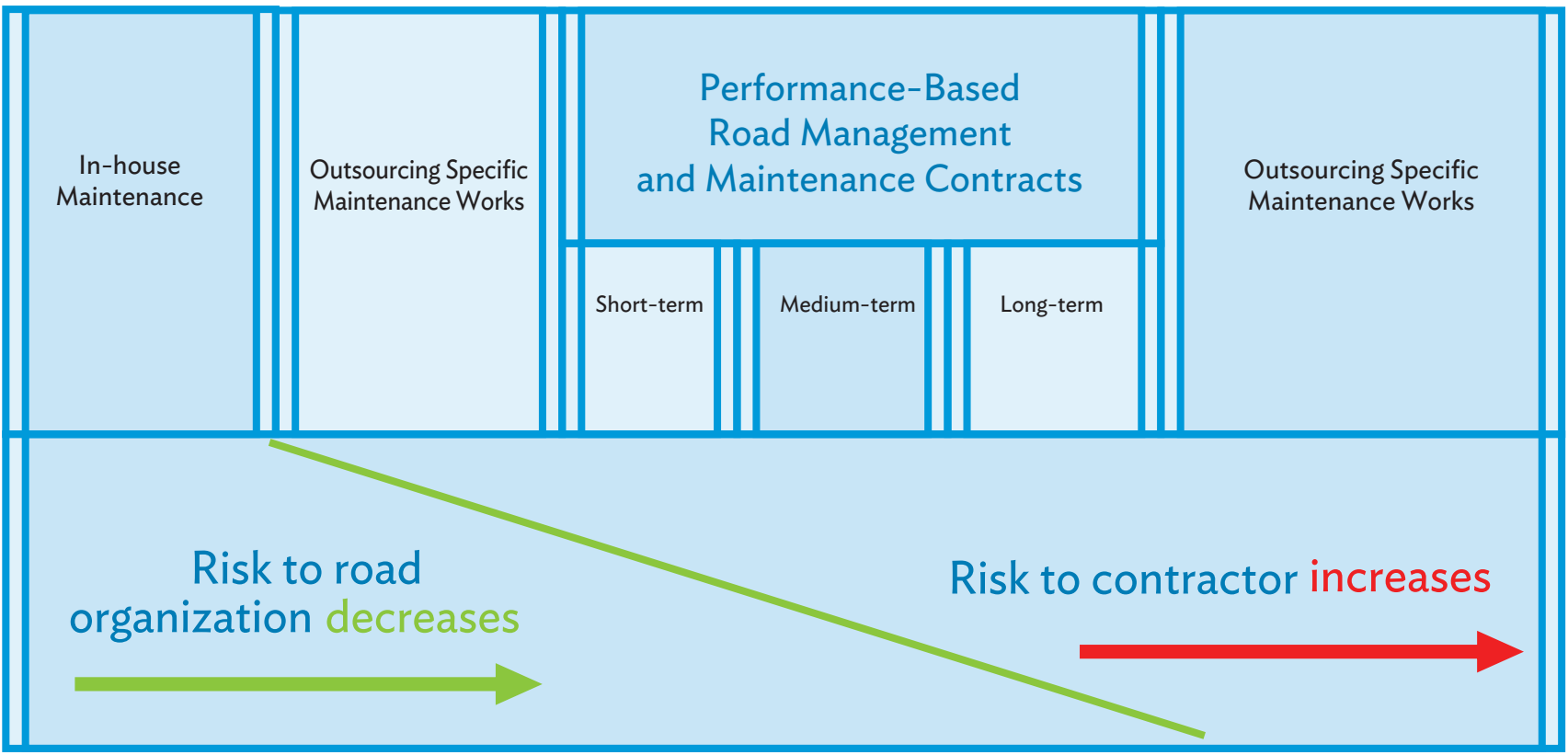

Source: G. Zietlow. 2004.

properly assess the consequences and budget them into their tenders. Asking the contractor to bear risks that could be best handled by the road organization or exceeds the ability of the contractor to realistically calculate the risks, will either result in withdrawal by the contractor, excessive tender prices, or losses to the contractor.

47. There is a clear relationship between the duration of a contract and the required qualifications of contractors. For medium- and long-term contracts, contractors need to be able to operate a pavement management system.
This is not required for shorter contracts, say up to 4 years. Table 5 illustrates the major risks distribution between client and contractor and how they might be mitigated. There might be additional country-specific risks, which need to be analyzed.

48. An example of risk sharing between road organization and contractor is included in the sample bidding documents from the Government of the State of Punjab, India. ${ }^{12}$ A risk management process manual can be retrieved from the website of the New Zealand Transport Authority. ${ }^{13}$

12 Government of India, State of Punjab, Public Works Department. 2011. http://www.prbdb.gov.in/files/oprc/OPRC\%20final.pdf

13 Government of New Zealand, Transit New Zealand. 2004. https://www.nzta.govt.nz/assets/resources/risk-management-process-manual/docs/riskmanagement-process-manual.pdf 
Table 5: Risk Distribution and Mitigation between Client and Contractor in Performance-Based Road Maintenance Contracts

\begin{tabular}{|c|c|c|c|}
\hline Risks & Client & Contractor & Mitigation \\
\hline Political, legal and regulatory & $x$ & & Client needs to bear the cost \\
\hline $\begin{array}{l}\text { Monetary and macroeconomic } \\
\text { risks }\end{array}$ & $x$ & & Client needs to bear the cost \\
\hline $\begin{array}{l}\text { Force majeure, including extreme } \\
\text { weather conditions }\end{array}$ & $x$ & & Client needs to bear the cost \\
\hline Lack of competition & $x$ & & $\begin{array}{l}\text { Contract scope and duration need to be adjusted to allow for sufficient } \\
\text { competition } \\
\text { Training programs for potential contractors }\end{array}$ \\
\hline Poor quality of works & & $x$ & $\begin{array}{l}\text { The contractor must follow the technical rules and regulations governing } \\
\text { road works. If there are no standards for road maintenance works, they } \\
\text { need to be developed. Spot checks of workmanship and quality of material } \\
\text { may be undertaken by the client. This is especially relevant for pilot } \\
\text { projects. }\end{array}$ \\
\hline Noncompliance with service levels & & $\mathrm{x}$ & $\begin{array}{l}\text { Strict application of payment reductions that need to be high enough to } \\
\text { deter contractors from noncompliance. Escalation clauses for payment } \\
\text { reduction shall be applied for successive noncompliance. }\end{array}$ \\
\hline $\begin{array}{l}\text { Premature termination of the } \\
\text { contract by the contractor }\end{array}$ & $x$ & & $\begin{array}{l}\text { Payment bonds shall be high enough to deter contractors from } \\
\text { terminating contracts prematurely. }\end{array}$ \\
\hline $\begin{array}{l}\text { Contractor does not have enough } \\
\text { information to realistically estimate } \\
\text { maintenance and winter services } \\
\text { cost }\end{array}$ & & $\mathrm{x}$ & $\begin{array}{l}\text { Client to supply the necessary data: } \\
\text { Construction details of the road } \\
\text { Maintenance history } \\
\text { Maintenance cost history } \\
\text { Road asset conditions } \\
\text { Winter weather history } \\
\text { If data are insufficient, unit prices for critical items shall be considered, } \\
\text { otherwise contractor will price the risk into his tender price. }\end{array}$ \\
\hline $\begin{array}{l}\text { Unexpected growth in traffic } \\
\text { volume or increase in overloading } \\
\text { of vehicles }\end{array}$ & & $\mathrm{x}$ & $\begin{array}{l}\text { Cost adjustment formula for unexpected traffic volume growth and } \\
\text { unexpected increase of overloading }\end{array}$ \\
\hline Inflation & & $\mathrm{x}$ & $\begin{array}{l}\text { Cost adjustment formula to take care of inflation reflecting the actual } \\
\text { inputs required for the PBC. }\end{array}$ \\
\hline Late payment & & $\mathrm{x}$ & Client to pay interest charges $1 \%$ over the borrowing rate of the contractor. \\
\hline Social acceptability risk & $\mathrm{X}$ & & $\begin{array}{l}\text { Involving road organization's staff early in the preparation of PBCs as well } \\
\text { as other stakeholders. }\end{array}$ \\
\hline
\end{tabular}

PBC $=$ Performance-based road maintenance contract.

Source: I. Greenwood et al. 2005. 


\section{Implementation Experiences}

49. PBCs have a relatively short history. The first contracts were implemented in 1988 in Canada, and the practice gradually spread all over the world.

50. PBCs in developed countries were mainly initiated by the road organizations themselves. The initiative to start PBCs in developing countries has usually been initiated by international financial institutions (IFIs), in particular, the World Bank ${ }^{14}$ and other regional development banks ${ }^{15}$ as well as bilateral development programs. ${ }^{16}$

51. PBCs differ widely in their complexity and duration of contract. An overview of the contract duration and the complexity of some of PBCs in some selected countries is illustrated in Figure 6.

52. The following section discusses how PBCs were implemented in different developed (Canada, Estonia, New Zealand, and the US); developing and transitional countries (Argentina, Indonesia, Malaysia, Serbia, and Uruguay); and CAREC countries (Afghanistan, Tajikistan, and Georgia), and identifies best practices.

\subsection{Developed Countries}

\subsubsection{Canada}

53. In 1988, the Province of British Columbia in Canada was a pioneer in outsourcing road maintenance under PBCs, with Alberta following in 1995 and Ontario in
1996. In 2006, British Columbia and Alberta maintained $100 \%$, and Ontario $60 \%$, of their provincial highways under hybrid type PBCs. All provinces took a stepwise approach, starting with 3- to 5-year contracts. Upon gaining experience, they gradually extended the PBCs up to 10 years. Contracts include routine maintenance and winter services, patrolling and emergency assistance. Periodic maintenance (resurfacing) and rehabilitations are excluded.

54. When the Province of British Columbia first introduced PBCs, they went from in-house road maintenance directly to PBCs. The government employees working in the road maintenance unit were offered the following options:

- Accept employment with the successful contractor in the district

- Stay with the government and fill vacant positions anywhere in the public service

- Take the early retirement package (if they were qualified)

- Resign

- Severance pay was not available under any option

55. At the end of the privatization for the first round of contracts in 1988, 2,280 employees were transferred to the new Road and Bridge Maintenance contractors, 20 employees stayed with the government, a few resigned, and about 200 took early retirement. In 1995, companies owned by ex-government employees held 16 contracts and controlled $57 \%$ of the total value of all 28 contracts. ${ }^{17}$

\footnotetext{
World Bank. 2014b.

European Bank. 2016.

16 G. Zietlow. 2004.

17 For more information of the PBCs in Canada see: World Bank. 2009. Resource Guide: Performance-Based Contracting for Preservation and Improvement of Road Assets. http://www-esd.worldbank.org/pbc_resource_guide/Case-Canada.htm.
} 


\section{Figure 6: Complexity and Duration of Selected Performance-Based Road Maintenance Contracts}

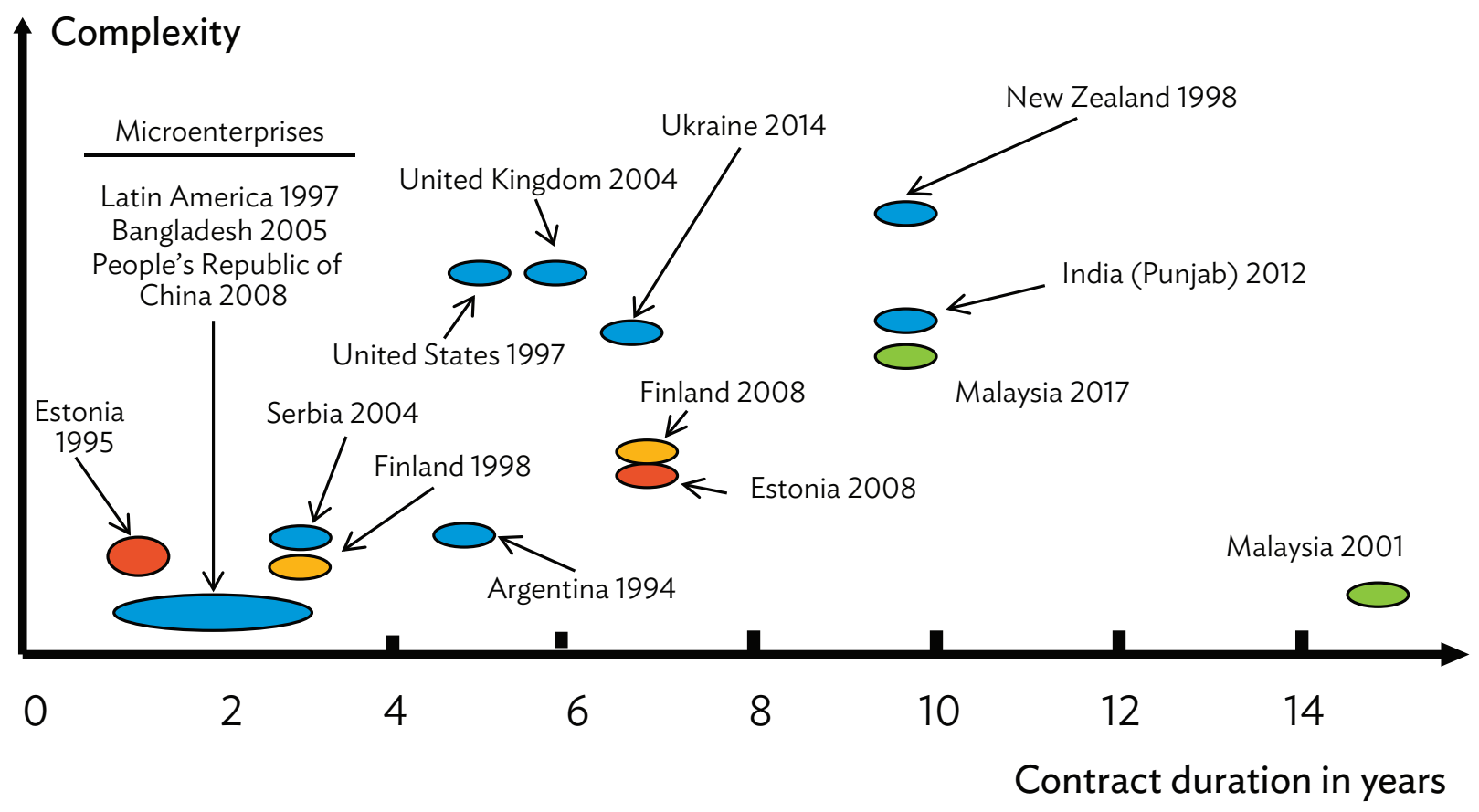

Source: G. Zietlow. 2015.

\subsubsection{New Zealand}

56. In 1998, Transit New Zealand awarded the first 10-year performance-specified maintenance contract (PSMC). Under this contract, the maintenance provider was responsible for maintaining the road network to meet a number of key performance indicators. Two years later, Transit New Zealand introduced a shorter version, socalled "hybrid" contracts, which incorporated features of conventional method-based and performance-specified maintenance procurement. These contracts typically run for a period of 5 years. By 2006, PSMCs were used on 15\% of the entire road network of New Zealand, predominately on national roads, which are generally sealed. At least one contract includes a mix of national and regional roads, with both sealed and unsealed roads. Recently, New Zealand introduced two new types of PBCs, the maintenance alliance mode ${ }^{18}$ and the operations and maintenance outcome contract (OMOC). ${ }^{19}$

57. The PSMC consists of a 7- to 10-year contract for providing all the products or services associated with state highway network maintenance and management. In a similar way to the hybrid model, the PSMC model utilizes output-based contracting, relying on self-compliance by the supplier to ensure performance. It strives to maximize the skills, expertise, innovation and systems of the road industry, expecting higher efficiency and improved value

18 World Bank. 2014a.

19 See OMOC documents in the New Zealand Transport Agency website: https://www.nzta.govt.nz/searchresults?term=OMOC. 
for money. The PSMC is a single lump-sum contract, which includes:

- Bringing the assets to the contracted standards, with a provision that changes in safety legislation (standards) become contractual;

- Provision of all inspections;

- Identification, programming, prioritization, and delivery of maintenance services necessary to achieve specified performance criteria; and

- Management of the integrity of the assets using a cost-effective long-term maintenance strategy.

58. Payments are monthly and are independent of actual works and services provided, but may vary subject to meeting performance criteria. ${ }^{20}$

59. Under the Hybrid Model, the client advised the quantum of renewal and rehabilitation works to be completed on an output basis, with all other maintenance activities to be completed on a lump sum basis for the outcome required. Contracts are typically 5-7 years in duration. In effect, the client retains the risk for the quantum of renewal works required while the contractor takes the risks associated with the quality of workmanship and the identification of the best location to undertake the works. A consultant is engaged to both monitor the performance of the contractor and to undertake the longterm asset management planning activities. ${ }^{21}$

60. Both the hybrid model and the PSMC will be gradually replaced by the new maintenance outcome contract model.

61. In an alliance model, the owner, contractor and consultant work as an integrated team to deliver specific activities under a contractual framework where their commercial interests are aligned with actual project outcomes. The key principle is that the Alliance assumes collective responsibility and takes collective ownership of all risks and opportunities, with an equitable share of the "pain" or "gain" of the project outcomes in comparison with the pre-agreed targeted outturn costs. The Alliance Model uses a specific type of cost reimbursement method that seeks to drive the required best for project behavior. The duration of contracts is between 7 and 10 years. ${ }^{22}$

62. Conventional Contracts are 3 to 5 years and range from input to output to outcome based and are used for specialist asset management activities like pavement repairs, emergency works, drainage, signage, delineators, litter control, vegetation control, pavement markings, bridge management, traffic counting and traffic operations centre. Figure 7 illustrates delivery modes for maintenance for each model by number and by value (\$/annum).

63. A review of the delivery models for PBCs in New Zealand is available online. ${ }^{23}$

\subsubsection{United States}

64. In December 1996, the Virginia Department of Transportation (VDOT) in the US awarded to VMS Inc. (VMS) a contract for asset management and maintenance of 1,250 lane miles or approximately 250 miles of interstate highways. The contract was developed on the basis of performance levels with clearly defined outcomes. This contract was the first road asset management and performance-based contract in the US and was an innovative approach to provide a high and well-defined quality of service to the user at lower cost.

65. Interestingly, VMS was an independent company with two consulting firms as prime investors, which made an unsolicited offer to VDOT for this contract, sensing that this line of business was especially suited to consulting firms and was going to have a great future in the US, which it was. VDOT estimated that this contract saved approximately

20 For more information on PBCs in New Zealand see: World Bank. 2009. Resource Guide: Performance-Based Contracting for Preservation and Improvement of Road Assets. http://www-esd.worldbank.org/pbc_resource_guide/Case-New\%20Zealand.htm; and World Bank. 2006.

21 The World Bank. 2014a.

22 Government of New Zealand, New Zealand Transport Agency. 2014.

23 OPUS. 2012. Review of Delivery Models for Works and Services. https://www.nzta.govt.nz/assets/resources/rmtf-report/docs-interim/delivery-modelsreport.pdf 
Figure 7: Contracts Used for Network Maintenance Management in New Zealand
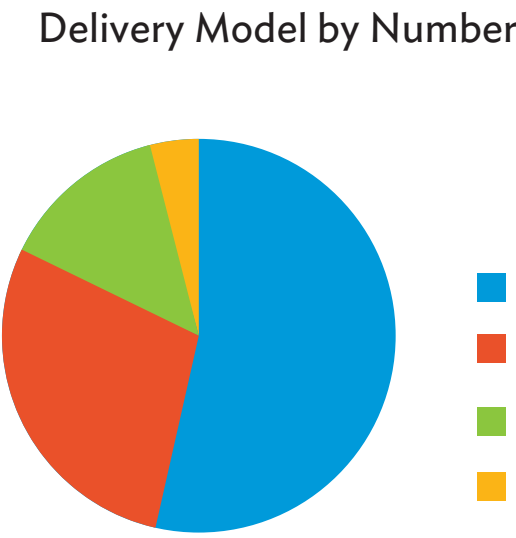

Traditional

Hybrid

PSMC

Alliance
Delivery Model by Value (\$/annum)

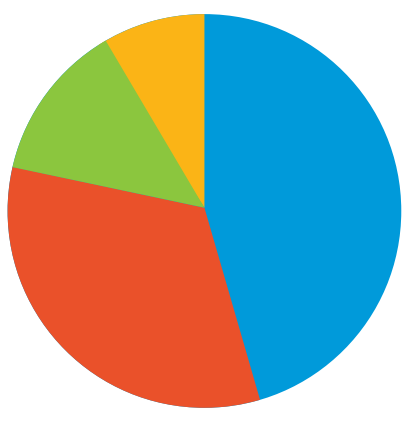

Traditional

Hybrid

PSMC

Alliance

PSMC = performance-specified maintenance contract.

Source: Government of New Zealand, Transport Agency. 2014.

$16 \%$ over the 5.5 -year contract period. This calculation was based on the assumption that the highway is maintained to its pre-existing condition. In December 2000, VDOT issued a report showing that actual conditions improved, resulting in further real savings.

66. In addition, VMS implemented a number of pavement material innovations and a crack seal program that improved the service life of the interstate highways as well as a mobile patcher. With a "just-in-time" delivery of maintenance services the contractor engaged resourceslabor, materials and equipment-on an as needed basis. This lowered total cost by avoiding excess inventory and underutilization of resources.

67. Under the contract, VMS was responsible for managing and maintaining the following features to preestablished outcomes:

- pavement

- $\quad$ roadside assets

- drainage system

- bridges

- vegetation and aesthetics
- traffic services

- emergency response services

- snow and ice control

68. Under the contract, VMS was also responsible for traffic control and assistance to the Virginia State Police and to local police and fire authorities. VMS' response time was 20 minutes during normal working hours and 40 minutes during non-working hours. After major incidents, VMS was assessed on its response times and its traffic control management. In addition, VDOT sent questionnaires to all nine Virginia State Police units along the interstate corridors managed by VMS. Responses indicated that VMS' performance was highly appreciated.

69. In-house staff provided approximately $15 \%$ of VMS services, with the other services subcontracted. In order to raise the quality of services of subcontractors and improve competition among them, VMS engaged in an extensive training program for small contractors. In this way, better quality could be provided at lower cost. ${ }^{24}$

70. Several other states in the US have also adopted $\mathrm{PBCs} .{ }^{25}$

24 K. Lande. 1999 and author's estimates.

25 W. Hymen. 2009. 


\subsubsection{Estonia}

71. In the 1990s, Estonia went through a privatization reform that also affected the road sector. The Estonian Road Administration (ERA) was encouraged to promote the creation of contracting firms and outsource road works to contractors. Private firms established at that time recruited mostly former government employees who were experienced in the execution of road works. In 1995, ERA started a pilot experience of performance-based procurement of road management and maintenance. From 1995 through 2000, ERA tested several 1-year and 2-year performance-based contracts. ${ }^{26}$ Several 5-year PBCs have been awarded between 2000 to 2005. Since 2007, contract duration has been extended to 7 years and as of 2008 , the entire $16,500 \mathrm{~km}$ road network administered by the ERA is maintained under PBCs. Estonia did not receive IFI loans to implement PBCs but did receive technical assistance from the Finnish Road Authority.

72. The scope of the PBCs covers routine and winter maintenance and minor emergency works on paved and unpaved roads. Resurfacing and rehabilitation works are not included. Performance monitoring comprises periodic informal and monthly formal inspections. While the informal inspections are performed by supervisors from the ERA, the monthly formal inspections are undertaken by a commission, which usually consists of three supervisors, one traffic person, and two representatives from ERA.

73. Road users are also encouraged to participate in the monitoring and evaluation of the contractors' work. Billboards with contact information are established along the contracted road corridors to encourage reporting of any deficiencies. Since the deployment of a PBC approach, ERA has noticed a decrease in the number of complaints from road users about road conditions. The winter road user surveys revealed that $50 \%$ of the polled road users considered the traffic conditions on main roads good or very good. This figure increased to $76 \%$ four years later.
74. Like British Columbia, Estonia shifted from in-house road maintenance to road maintenance contracts. Since it began outsourcing routine maintenance works to PBCs, ENRA had to substantially reduce its workforce since it needed fewer workers to continue executing other kinds of road works and fewer administration staff to administer and supervise PBCs. ${ }^{27}$ Many of its former employees ended up working for the PBC contractors (see Figure 8).

\subsection{Developing and Transitional Countries}

\subsubsection{Serbia}

75. In 2004, Serbia started two hybrid type pilot PBCs, which covered routine and winter maintenance as well as routine bridge maintenance. At that time, many routine maintenance works were still paid on a unit price basis. Both contracts had 3-year terms, with a 2-year extension, if the contractor performed well and agreed to continue. Unfortunately, both pilot projects were discontinued after 3 years and 7 months due to lack of funds. ${ }^{28}$ The PBCs covered $660 \mathrm{~km}$ of regional roads in one district and $517 \mathrm{~km}$ of regional roads in the other district. The pilot projects were financed jointly by the World Bank and the Government of Serbia.

76. One international and five domestic contractors participated in the international tendering. One contract was awarded to the international contractor and the other to one of the domestic contractors. Supervision was outsourced to a local consulting firm since nobody in the road administration was willing to do the job, due to their low salaries.

77. The main challenge that the client and the contractors faced was the lack of sufficient qualified staff with the road administration, consultants, and contractors. The consulting firm that produced the bidding documents and

26 World Bank. 2009.

27 For more information on PBCs in Estonia, see World Bank. 2009. http://www-esd.worldbank.org/pbc_resource_guide/Case-Estonia.htm.

28 For more information on the pilot projects, see World Bank. 2009. World Bank. http://www-esd.worldbank.org/pbc_resource_guide/Case-SerbiaMn.htm. 


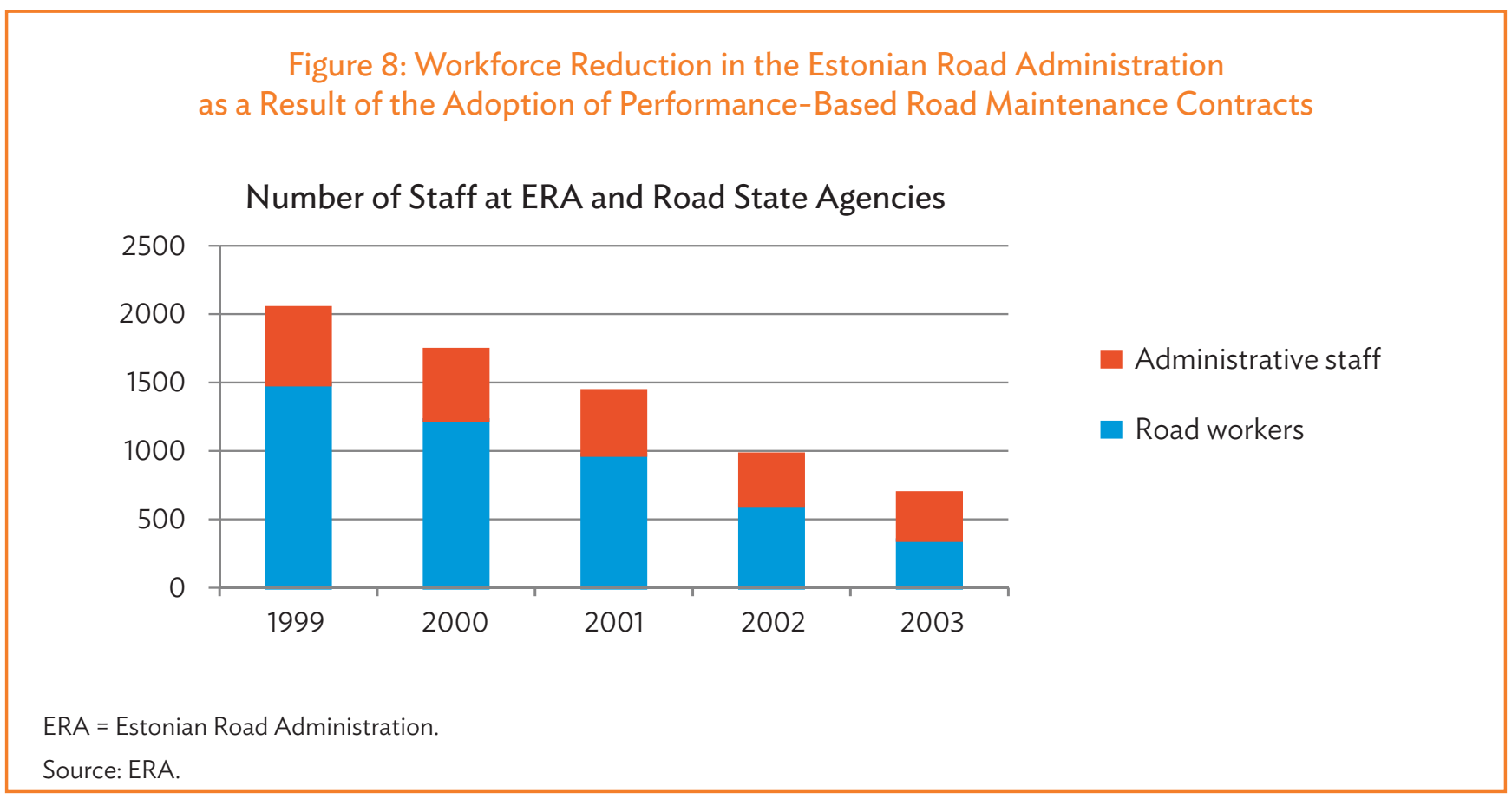

assisted during the bidding process held training courses but they were considered insufficient. A coaching and training consultant, at least for the first 2 years of the contract, would have helped to solve this problem.

78. Nevertheless, both PBCs were considered successful, since they significantly improved road conditions, reduced routine maintenance cost by an average of $49 \%$, and reduced winter maintenance by an average of $52 \%$ compared with the central region of Serbia during the same period. The savings achieved for winter maintenance were due to the savings in salt and aggregates. Instead of applying the amount of salt and aggregate as specified in the technical rules, skid resistance was used as a performance level (see Figure 9). ${ }^{29}$

\subsubsection{Argentina}

79. Because of the financial crisis in Argentina in 1990, the national road administration awarded several concessions for approximately $10,000 \mathrm{~km}$ of national roads which carried enough traffic to justify road tolls.
The concessionaire controlled axle loads by installing and operating weighbridges. Since the contractors did not have enforcement powers, they entered into agreements with the local police for assistance.

80. In 1996, the national road administration started PBCs known as CREMA (Contrato de Rehabilitación y Mantenimiento or Road Rehabilitation and Maintenance Contracts) with financial assistance from the World Bank. The program was implemented in two phases. The first phase involved $11,000 \mathrm{~km}$ of national roads that carried between 250 and 2,500 vehicles a day. Due to the poor condition of the roads, rehabilitation costs represented $75 \%-80 \%$ of the total contract amount. The initial bidding contracts were awarded to mostly local contractors. Each contract covered between $100 \mathrm{~km}$ and $300 \mathrm{~km}$. In the subsequent second phase, another $8,200 \mathrm{~km}$ of national roads were contracted under road rehabilitation and maintenance contracts. Today, PBCs cover the entire national and part of the provincial road network of Argentina. ${ }^{30}$

29 For more details on the winter maintenance performance levels used in Serbia and Montenegro see Bidding Document for Routine and Winter Maintenance-Specifications, see World Bank. 2009. http://www-esd.worldbank.org/pbc_resource_guide/BiddingDocs.htm.

30 See World Bank. 2009. http://www-esd.worldbank.org/pbc_resource_guide/Case-Argentina.htm. 
Figure 9: Comparison of Winter Maintenance Unit Costs for Pilot Projects in Serbia against Costs from Central Serbia

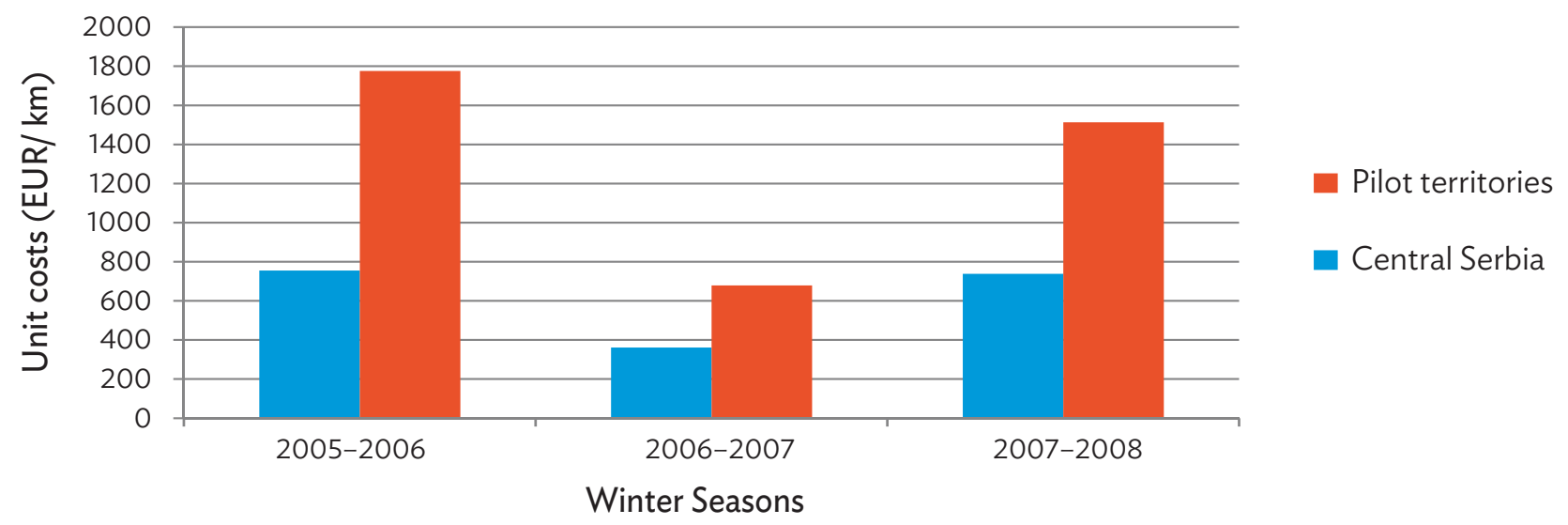

EUR = euro; $\mathrm{km}$ = kilometer

Source: N. Radovic et al. 2014.

81. Success factors identified by the World Bank include the following: ${ }^{31}$

- Delays in project implementation were minimized by the requirement for contractors to carry out detailed engineering designs before initiating the works. This enabled the World Bank to disburse its funds rapidly.

- Government supervision costs decreased substantially as contractors were required to perform their own quality control.

- Lump-sum contracts practically eliminated cost overruns.

- By making the long-term payment obligation legally binding on the government, the CREMA established a mechanism to ensure that Treasury provides funding for road maintenance. Experience during implementation showed that in times of fiscal constraints $(1998,1999$, and end2001), the budget process respected the CREMA contracts and funds were allocated to them in priority, as a nondiscretionary expenditure.
- Performance levels were simple enough to apply and monitor by a much-reduced inspection team consisting generally of one engineer and one laboratory technician, and the desired results were obtained.

- The system fostered innovation in the programming and execution of works, since payments were tied to outcomes and not to rigid specifications on materials standards or workmanship.

- The contractor's obligation to maintain the roads over a 5-year period reduced the risk of unsatisfactory quality in the rehabilitation and subsequent maintenance works.

- In terms of cost efficiency, the system proved superior to conventional unit price contracts. Ex post economic evaluation of the first generation of CREMAs showed that the rehabilitation and maintenance funding yielded an economic rate of return of $60 \%$, at a $12 \%$ cost of capital. The contracts reduced the need for future capital investments by nearly $30 \%$. 
Competition during bidding, combined with the fact that only one of the 60 contracts was cancelled due to contractor financial difficulties, suggest that these contracts were financially attractive to the private sector. Comparing the unit costs of the CREMAS rehabilitation works to those achieved in the more conventional admeasurement contracts, such as the ones used in the Provincial Roads Project, showed that the long-term performance-based system was, overall, more cost-efficient.

\subsubsection{Uruguay}

82. In 1996, the Ministry of Public Works in Uruguay started its first pilot PBC on national roads initiated by a German Technical Assistance Program. ${ }^{32}$ Two types of contracts were rolled out: one covered only routine maintenance, and the other included initial rehabilitation and periodic and routine maintenance.

83. The routine maintenance-only contract was developed to give employees of the Ministry of Public Works an opportunity to form their own private enterprises, thus reducing Ministry staff numbers. To provide security, staff were given the opportunity to return to the ministry during the first year of the contract in case the contracting arrangement failed. No failures occurred and consequently more staff wanted to form companies than new contracts could absorb. Road conditions improved substantially.

84. The other contract that included initial rehabilitation and periodic and routine maintenance was piloted with excellent results. Since actual road conditions were substantially below the contract performance standards, the contractor was given between 3 and 12 months to upgrade the roads to the required standards.

85. By January $2000,42 \%$ of the national road network was being maintained by performance-based road maintenance contracts. Key to the program's success was careful planning and implementation of contracts, combined with the strong commitment and support from the Minister of Public Works. Due to legal restrictions, contract duration was limited to 4 years.

86. Also in 1996, the capital city of Montevideo started the first PBC for $138 \mathrm{~km}$ of its city roads. Deficiencies in parts of the road network required initial spot rehabilitation paid for on a unit price basis. The 3-year contract allowed for a 3-year extension, where the monthly fixed payments were reduced by $40 \%$ during the extension period. ${ }^{33}$

\subsubsection{Malaysia}

87. In 2001, the Public Works Department of the Ministry of Works in Malaysia introduced performance-based area contracts for the entire federal road network, except for areas managed under toll concessions. The main reason for introducing long-term PBCs was to secure long-term funding for road maintenance and to guarantee good road conditions. Both objectives have been fulfilled.

88. The Malaysian peninsula was divided into three areas (with lengths of 3,075 km; 4,000 km; and 7,498 km) each covered by a different contract each with a 15-year term. The PBCs cover routine and periodic maintenance. Not all the routine maintenance works are performance-based, as some of them are cycled works.

89. Since 2014, the Public Works Department has been in the process of extending the PBCs for another 10 years, provided that the offers presented by the contractors are those where all routine maintenance are performancebased, and will provide better value for money than the existing PBCs.

\subsubsection{Philippines}

90. In 2003, the Philippines started three 3-year pilot PBCs under the National Roads Improvement and Management Program (NRIMP I) for backlog maintenance, routine, and periodic maintenance for $112 \mathrm{~km}, 109 \mathrm{~km}$, and $33 \mathrm{~km}$ roads. Only routine maintenance was paid on a lump sum

32 G. Zietlow. 2004.

33 For more information on the PBCs in Uruguay see G. Zietlow. 2006. http://www-esd.worldbank.org/pbc_resource_guide/Docs-latest\%20edition/ cases-and-pdfs/5_PBC_Uruguay.pdf. 
basis, while backlog and periodic maintenance was paid on unit price basis. The contracts were undertaken by foreign contractors and supervised by the Department of Public Works and Highways (DPWH). All the PBCs achieved their objectives but success was hampered by the following:

- The fact that the PBC concept was new to the contractors and DPWH. Neither the contractors nor DPWH staff understood the PBC concept, nor did they receive training or coaching on how to manage the contracts.

- Little information was provided to the potential contractors on the history and actual condition of the road, exposing the contractors to unreasonable risks that might have contributed to higher cost estimates. In addition, pumping problems ${ }^{34}$ in one contract should have been detected by the client at an earlier stage. If historical data on this road section had been available, this problem would certainly have been detected earlier.

- Monthly formal inspection of defects was made jointly by the contractor and the client on the total length of the roads under contract and formed the basis for determining only the starting date of the response times, thus, there was no incentive for the contractor to act proactively.

- There was persistent concern that penalties were not being rigorously enforced; in addition, the amount of penalties was rather low.

- The contracts had short duration, where the routine maintenance components represented only $14 \%$ of the contract prices. ${ }^{35}$

91. Since 2014, longer term PBCs are being implemented under NRIMP II. The scope includes backlog elimination, routine and periodic maintenance, and rehabilitation works.

\subsubsection{Other Case Studies}

92. The World Bank PBC Resource Guide ${ }^{36}$ features additional country case studies for Australia, Brazil, Chad, Denmark, Finland, Peru, South Africa, the UK, and the US.

93. In addition, the World Bank ${ }^{37}$ has reviewed PBCs in Argentina, Australia, Brazil, Chad, Egypt, India, Liberia, New Zealand, Nigeria, the Philippines, Poland, Tanzania, and Zambia. Some of the important conclusions of the study are the following:

- Some PBCs failed to get implemented because the relevant government institutions were not convinced of the concept, the failure to appoint qualified consultants to prepare the bidding documents, insufficient local funding, or insufficient competition by qualified contractors.

- However, very few PBCs failed once implemented. To make it through the full PBC process, the project requires strong champions in the road organization and the ministry of finance.

- PBCs offer a procurement model that is more resistant to corruption than conventional contracts because of fewer transactions involved and more transparency, which also facilitated easier audits.

94. Three more papers covering the experiences of implementing $\mathrm{PBCs}$ are International Overview of Innovative Contracting Practices for Road, ${ }^{38}$ PerformanceBased Contracting for Maintenance-A Synthesis of Highway Practice, ${ }^{39}$ and Policy Challenges in the Implementation of Performance-based Contracting for Road Maintenance. ${ }^{40}$

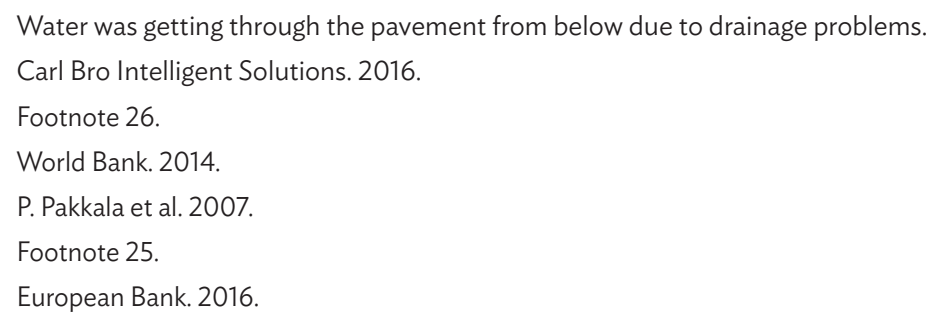




\subsection{Central Asia Regional Economic Cooperation Countries}

\subsubsection{Afghanistan}

95. Afghanistan started its first pilot PBC in 2006 on $142 \mathrm{~km}$ of a newly reconstructed road between Kabul and Jalalabad, funded completely by the EU. The contract was for 3 years and the scope included traffic management, routine and winter maintenance, repair and emergency works, and the operation of two weigh stations (in Kabul and in Jalalabad). Routine and winter maintenance was paid on a lump sum basis, while all other works were paid on a unit price basis. Snow clearing was part of emergency works and paid on a unit price basis.

96. Although Afghanistan had no history of road maintenance contracting, five local contractors participated in the local bidding, of which three qualified to be evaluated. Supervision was done by Ministry of Public Works (MOPW) staff, who received training at the start of the project. ${ }^{41}$

97. From 2008 to 2011, road rehabilitation and maintenance works were performed under two United States Agency for International Development (USAID)-funded programs. ${ }^{42}$ A total of $1,877 \mathrm{~km}$ of national highway, secondary and provincial roads were rehabilitated and maintained by a foreign management contractor. The contractor developed performancebased road maintenance contracts that were appropriate for Afghanistan and which gave due consideration to the technical and contracting capabilities of Afghan road contractors and the prevailing security conditions.

98. A relatively independent Road Maintenance Unit (RMU) was established within the MOPW to plan annual work programs, prepare and award PBCs, and manage the maintenance of the USAID-funded roads. The PBCs included routine road maintenance and emergency repairs.
99. During the first year, works contracts were awarded for a term of 6 months with 2-month extensions. Subsequently $1,500 \mathrm{~km}$ of roads were divided up into five packages and awarded to Afghan subcontractors. Training activities began in 2008 with RMU and MOPW staff, followed by private sector subcontractors. The performance of the Afghan subcontractors was mixed, and the RMU was dissolved after the program ended in $2011 .{ }^{43}$

100. The implementation of PBCs in Afghanistan is still not sustainable and requires a holistic approach to secure long term financing, an appropriate institutional framework, and a human resource development program.

\subsubsection{Tajikistan}

101. Since June 2013, the Government of Tajikistan has been financing two 3-year pilot PBCs through its regular road maintenance budget, one for $73 \mathrm{~km}$ and the other for $76 \mathrm{~km}$ of national roads. ADB assisted in the project preparation. The scope included routine and winter maintenance, repair works, and emergency works. The repair works to bring the road asset up to the required performance levels were $31 \%$ and $16.4 \%$, respectively, of the contract price for the two contracts. ${ }^{44}$

102. Unit costs for the routine maintenance of the contracts are shown in Table 6 . These costs are slightly higher than routine maintenance costs in countries exhibiting similar characteristics, especially considering that winter maintenance costs are excluded. Factors that may contribute to higher routine maintenance costs are:

- the cost of performing deferred maintenance to bring the road to a condition in which service levels are met; and

- unfamiliarity with PBC contracting on the part of the local contracting industry causing them to allocate a cost for perceived higher risk.

41 G. Williams. 2008.

42 Rehabilitation of Economic Facilities and Services Program and Afghanistan Infrastructure and Rehabilitation Program.

43 USAID. 2012

44 ADB. 2015. 
103. Road conditions improved substantially during contract execution. Road users interviewed were satisfied, especially with the quality of winter services. Table 7 illustrates the performance rating at the beginning of the contract in July 2013 and in July 2015.

104. Based on the success of the PBC pilot projects, the government of Tajikistan and ADB intend to leverage the experiences gained on the Nurobod-Nimich and VahdatObi Garm by entering into two new PBC pilot contracts. These roads are the Sayron-Karamyk road $(88 \mathrm{~km})$ and the Vose-Khovaling road $(87 \mathrm{~km})$ scheduled to be rehabilitated and upgraded under the proposed ADB grant to Tajikistan for the CAREC Corridor 3 and 5 Enhancement Project.
105. The per kilometer costs for the proposed PBC projects are likely to be significantly lower than the recently concluded pilot PBCs since the former will be implemented immediately after rehabilitation. This means that routine maintenance cost will be lower because deferred maintenance and repair works will not be required.

106. To fully leverage the potential of PBC as a cost-effective service delivery mechanism, it is recommended that:

- contract provisions for penalties for failure to meet service levels be more strictly enforced;

- contract requirements for written work orders for winter maintenance and emergency works be fully implemented;

Table 6: Annual Routine Maintenance Cost of Roads in Tajikistan $(\$ / \mathrm{km})$

\begin{tabular}{|c|c|c|c|c|c|}
\hline \multicolumn{2}{|c|}{$\begin{array}{c}\text { Lot 1 } \\
\text { Nurobod to Nimich }\end{array}$} & \multicolumn{2}{c|}{ Lot 2 } \\
\hline $\begin{array}{c}\text { Expenditure to } \\
\text { Date } \\
(\$)\end{array}$ & $\begin{array}{c}\text { Length } \\
(\mathrm{km})\end{array}$ & $\begin{array}{c}\text { Annual Cost } \\
\text { per km }\end{array}$ & $\begin{array}{c}\text { Expenditure to } \\
\text { Date } \\
(\$)\end{array}$ & $\begin{array}{c}\text { Length } \\
(\mathrm{km})\end{array}$ & $\begin{array}{c}\text { Annual Cost } \\
\text { per km }\end{array}$ \\
\hline 341,871 & 73 & 2,342 & 347,067 & 76 & 2,283 \\
\hline
\end{tabular}

$\mathrm{km}=$ kilometer .

Source: ADB. 2015.

Table 7: Performance Monitoring Compliance Rating in Tajikistan

\begin{tabular}{|l|c|c|}
\hline \multirow{2}{*}{ PBC Contract } & \multicolumn{2}{|c|}{ Compliance Rating } \\
\cline { 2 - 3 } & July 2013 & July 2015 \\
\hline Lot 1 Nurobod-Nimich & 79.95 & 97.95 \\
\hline Lot 2 Vahdat-Obi Garm & 76.66 & 92.05 \\
\hline
\end{tabular}

$\mathrm{PBC}=$ performance-based road maintenance contract.

Source: ADB. 2015. 
- $\quad$ PBC pilot testing program with the objective of improving contract documents be continued;

- contract requirements for submitting and complying with a quality assurance program be more strictly enforced;

- competition is increased by providing more awareness training for local contractors to expand the pool of contractors interested in competing for PBC contracts;

- local contractors are ensured a level playing field to enhance competition.

\subsubsection{Georgia}

107. In 2015, Georgia started its first PBCs for the rehabilitation and maintenance for $117 \mathrm{~km}$ of roads in Kakheti Region for a duration of 60 months. ${ }^{45}$ This pilot PBC, which was financed through a World Bank loan, was well accepted by the Roads Department as a solution to achieve long-term savings of road maintenance cost and to improve road conditions. Encouraged by the success of the pilot project and positive feedback from local contractors, the Roads Department intends to expand the PBC approach and make the local construction industry familiar with the concept.

108. Presently, Georgia is planning to implement PBCs on $250 \mathrm{~km}$ of roads in Guria region. The contract includes rehabilitation and maintenance works, and will be financed by an existing World Bank loan.
109. In addition, ADB is preparing to extend a loan to Georgia to maintain $200 \mathrm{~km}$ of international and secondary roads based on performance based maintenance. ${ }^{46}$

\subsubsection{Other PBCs Implemented or Planned in CAREC Member Countries}

110. Pakistan has implemented PBCs on $1,268 \mathrm{~km}$ of its national road network recently.

111. Mongolia is planning to contract $303 \mathrm{~km}$ of roads between Oyu Tolgoi and Khangi under the PBC scheme. The pre-feasibility study is under way. An additional 1,907 $\mathrm{km}$ of roads are expected to be maintained under PBCs as soon as financing becomes available through the state budget.

112. Azerbaijan is planning to use PBCs on four state roads for a total of $982 \mathrm{~km}$ beginning in 2018.

113. The Kyrgyz Republic is planning a pilot PBC on a section of Bishkek-Osh road, starting from Kara Balta to $\mathrm{km} \mathrm{161,} \mathrm{with} \mathrm{total} \mathrm{length} \mathrm{of} 101 \mathrm{~km}$. The objective is to draw as much experience as possible from the pilot contract to assist the possible wider deployment of PBCs on other parts of the road network. 


\section{Lessons Learned}

114. PBCs have become a well-accepted and established form of managing and maintaining roads worldwide and are gradually replacing the conventional way of contracting. Countries across the world have realized that PBCs

- deliver good value for money. Moving away from conventional road maintenance contracts in favor of PBCs have resulted in savings of between $20 \%$ and $30 \%$, based on the same level of service. Healthy competition between qualified and innovative contractors, long-term contracts, and a balancing of risks between the client and contractors are the main drivers for cost savings. Where these conditions are not met, PBCs might not produce savings and may even result in higher prices compared to conventional contracts.

- provide better guarantee of sufficient funding for road maintenance. Since road maintenance is heavily underfinanced in almost of the developing countries, medium- and long-term PBCs can help solve this problem. Good examples are Malaysia, Argentina and Uruguay.

- improve road conditions, help reduce road user cost, and improve road safety. All PBCs have resulted in better road conditions on the roads under contract; consequently, they have reduced the risk of accidents, contributed to shorter travel times, and reduced vehicle operating costs.

- help to save substantial amounts of road rehabilitation and reconstruction work. As a rule of thumb, each $\$ 1$ spent in time on routine maintenance saves between $\$ 4$ and $\$ 6$ on necessary rehabilitation or reconstruction works later on, in constant prices.

- provide better expenditure certainty for the road agencies. Contractors are generally paid fixed monthly installments throughout the contract period and variation orders are minimized or even excluded.

- increase private sector willingness to contribute to road maintenance. PBCs provide good and stable road conditions and help increase the willingness of road users to pay for road use.

115. The past 25 years have led to many lessons and best practices on PBCs that have been adopted worldwide. This report concentrates on lessons applicable to developing and transitional countries, as they are considered most relevant to supporting the implementation of PBCs in CAREC countries.

116. First, PBCs need a conducive environment for successful implementation. The most important factors are

- strong commitment and support by key decision makers, especially from the ministry of finance, the ministry in charge of roads, and the road organization;

- a positive attitude from road organization staff;

- client, contractors, and consultants have the capacity to plan and manage this new kind of contract;

- an adequate road asset management system to support the requirements of $\mathrm{PBCs}$;

- long-term funding; and

- a competitive road maintenance market.

117. Second, the best way to implement PBCs is to take a gradual approach cognizant of the level of experience of all market stakeholders. Pilot projects help test the feasibility of PBCs and increase the experience and confidence of stakeholders, who can then implement contracts with greater scope, increased complexity, and longer duration. 
118. Third, risks should be assumed by the party who can best manage them. Burdening the contractor with risks they cannot quantify or mitigate may lead to higher prices, or even the premature termination of the contract.

119. Fourth, pilot projects need careful preparation and need to be tailored to the specific conditions in each country. A detailed road condition survey, realistic cost estimates, and well-designed bidding documents contribute to the successful implementation of PBCs.

120. Fifth, effective supervision is a crucial factor for success, especially in developing and transitional countries.
121. Sixth, pilot PBCs need coaching and training, at least during the initial phase, until all parties involved are sufficiently familiar with the concept. Since PBCs need a change in mindset, the time it takes to fully grasp the concept should not be underestimated.

122. Seventh, very few PBCs initiated by an international financial institution (IFI) have failed once implemented; however, a few do fail to get implemented for various reasons, such as a lack of interest from the road organization or a lack of competition.

123. Eighth, PBCs have offered a procurement model that is more resistant to corruption than conventional contracts because of fewer transactions involved and more transparency, which also facilitated better audits. 


\section{Performance-Based Road Maintenance Contracts Implementation Strategy in CAREC Member Countries}

124. This section discusses how PBCs can be rolled out in CAREC countries most effectively, based on the broad lessons learned from implementing PBCs across the world.

\subsection{Create an Enabling Environment and Meet Preconditions}

125. The successful and sustainable implementation of PBCs requires an enabling environment with several preconditions including (i) an effective and efficient institutional and regulatory framework; (ii) sufficient longterm road maintenance funding; and (iii) well-qualified road maintenance contractors in a competitive market.

126. In most CAREC countries, there is a large scope to improve the efficiency of their road sector institutions, ensure the sufficiency of funds assigned to road maintenance, contract out maintenance as opposed to performing such functions in-house, and reduce the overloading of vehicles. These pose special challenges for the implementation of PBCs and need to be addressed as part of a wider strategy on road asset management. As conditions differ in each CAREC member country, tailormade solutions are required.

127. Nevertheless, there are common methods on how to address these problems. The first step would be to raise awareness among decision makers about the inefficiencies of the road sector, especially regarding road maintenance, and consequently, the negative effects to the national economy. This could be done through a road sector study that will analyze the existing institutional, regulatory, financial, and technical framework as well as the bottlenecks that impede the effectiveness and efficiency of road maintenance. A road map to address these issues should then be designed. In this context, an analysis is required to determine how the introduction of $\mathrm{PBCs}$ can help create more value for money.

128. A strategy on how to implement PBCs in the medium and long term needs to be defined. The conclusions need to be disseminated at the highest political level, especially at the cabinet level, to clearly demonstrate the economic losses caused by the present road sector policies, and what needs be done to improve the situation, with special emphasis on PBCs.

129. Other stakeholders need to understand the concept of PBCs. This can be done through presentations, seminars and workshops for key decision makers, road agencies, contractors, consultants and other interested parties. It is important to highlight the potential benefits of PBCs for each group of stakeholders.

130. Discussions with road agencies of other countries that have successfully implemented PBCs may help stakeholders form a better understanding of PBCs and to avoid making similar mistakes in their implementation. Study tours for key decision makers to such countries may help in securing high-level support for the new contracts scheme.

131. The most important issue is securing sufficient funding for road maintenance, not only for one or several pilot projects, but for the long term. Once road maintenance is covered by PBCs, they need to remain under PBCs to guarantee minimum performance levels in the future. In almost all CAREC countries, road maintenance is severely underfinanced. This is especially true when road maintenance is financed through the ordinary budget. Allocating road funds or providing for higher road 
maintenance funds may help to ease the problem, but even then, it would not necessarily guarantee sufficient funding for road maintenance. To reach a sustainable level of road maintenance financing, the government needs to adopt a fundamental shift in policy, and obtain IFI support. ${ }^{47}$

132. The institutional framework needs to be conducive to implementing PBCs. Separating the planning and management of roads, from the implementation of road works, and contracting out implementation to the private sector, is a prerequisite to start PBCs. In addition, a wellfunctioning procurement and/or tendering system with a competent procurement unit is an important determinant to guarantee a transparent and competitive tender process.

133. For PBCs to be successful, a strong commitment is required from all levels of the road organization, especially from the highest levels. Individuals at mid-level also need to champion the PBC process. Road organizations that still conduct routine road maintenance through their own labor force will have to start contracting out this work to the private sector, or at least have a strong commitment toward privatization of road maintenance before embarking on their first PBC pilot project.

134. Existing laws and regulations need to allow for shortand long-term PBCs and for multi-year financing. If supporting legislation is not in place, laws and regulations will first need to be amended. The same applies to road regulations and technical rules that are not consistent with the PBC concept.

135. Overloading of vehicles severely shortens the life of pavements and seems to be a major concern in all CAREC countries. Even if the respective laws and regulations are in place, fines are normally too low and enforcement is almost non-existent. Effective enforcement of axle load limits can substantially reduce road maintenance costs. More effort is therefore needed to control overloading. If the government cannot control overloading then the design of the PBC needs to take this into account, either by including a price adjustment formula for overloading beyond an expected range, designing the pavements for higher loads, or by allowing the contractor to control overloading. ${ }^{48}$ The best way to stop overloading is to increase fines to discouraging levels, or to physically stop overloaded vehicles from continuing their journey. If possible, the contractor should be put in charge of axle load control, which would require police support for effective enforcement.

136. For road agencies with experience in contracting out routine road maintenance to the private sector, the next step to implement PBCs is relatively simple. Road agencies need to create a PBC unit within the organization with sufficient and qualified staff. A shortage of qualified staff, as may be the case in many CAREC countries, might pose a serious problem. Staff qualifications and experience can be improved through training and coaching to enable them to properly prepare, supervise and monitor PBCs. For pilot projects, this task can be undertaken by a qualified consultant.

137. It is also important to acknowledge that effective competition is required to keep costs low. Short-term and long-term measures will have to be taken to develop both the contracting and the consulting industry to face the challenges of implementing PBCs.

138. For the successful and sustainable implementation of PBCs, a well-qualified contracting and consulting industry is vital. There should be an assessment of the capacity of the road organization, contractors and subcontractors, as well as consultants to implement PBCs, in order to identify deficiencies and define what can be done to overcome them. This assessment will have a major impact on the design of the pilot PBCs. Appendix 2 provides a methodology on how to assess these capacities.

\subsection{Design a Performance-Based Road Maintenance Contract Well}

139. Designing a PBC requires (i) technical studies covering the selection of candidate roads; determining the scope of works and services, and the duration of the contract;

47 See section 5.6: Role of International Financial Institutions.

48 There are several developing countries that have allowed contractors to control overloaded vehicles by fixed weigh stations and/or portable weigh scales. 
undertaking a detailed road assets condition survey; determining the right mix between unit rates, lump sums and performance-based works and services with adequate performance levels; estimation of the likely costs; and a risk assessment and mitigation strategy; (ii) design of tender documents; (iii) supplying data to tenderers; and (iv) appropriate supervision arrangements.

\section{A. Technical Studies}

140. Selection of candidate roads: The most important selection criteria are the road conditions, importance of the road, and ease of access for contractors. Other factors that may be taken into consideration are shown in Table 8.

141. Determine the duration of contract: The duration of the contract is influenced by the available funds, scope of the contract, and the qualification of the contractors. Contracts covering routine maintenance only can be shorter than contracts with substantial amounts of capital works (see recommended options for PBC in Chapter 6). The better the qualifications of a contractor, especially regarding their ability to forecast pavement deterioration patterns, the longer can be the contract duration.

142. Carry out detailed condition surveys: Detailed road condition surveys are required to estimate the likely cost of the contract. Since roads often tend to deteriorate rapidly, surveys might need to be updated if there are major delays in the award of the contract. The road surveys should be made available to the tenderers to enable them to make an informed bid.

143. Determine the mix between unit rates, lump sums and performance-based works and services: This mix mainly depends on the qualifications of the contractor. The better qualified the contractor, the more works and services can be paid on a performance basis.

144. Determine adequate performance levels: There are two types of performance levels: management, and operational. Management performance levels need to make sure that the contract is adequately managed by the contractor and allows the road organization to monitor the PBC effectively. Operational performance levels mainly depend on existing technical regulations, affordability, traffic volumes, scope of works and services, measurability
Table 8: Selection Criteria Used to Identify Pilot Site for Performance-Based Road Maintenance Contract in Indonesia

\begin{tabular}{|l|c|}
\hline Criteria & Importance \\
\hline $\begin{array}{l}\text { Knowledge of PBC concepts and desire to } \\
\text { make PBC work by local DGH staff }\end{array}$ & Very High \\
\hline Operational asset understanding & Very High \\
\hline Capacity of the local industry & Very High \\
\hline $\begin{array}{l}\text { No significant events that may affect the } \\
\text { future management of the road }\end{array}$ & Very High \\
\hline Robust asset data & Very High \\
\hline Location of weighbridges & Very High \\
\hline Maintain local competition & High \\
\hline $\begin{array}{l}\text { Size of the contract that the local industry } \\
\text { can handle }\end{array}$ & High \\
\hline $\begin{array}{l}\text { Risks that are not significantly higher than } \\
\text { elsewhere on the network }\end{array}$ & Medium \\
\hline Reliability of traffic loading forecasts \\
\hline Availability of resources to all contractors \\
\hline $\begin{array}{l}\text { Value of initial improvement works } \\
\text { Historical maintenance cost data }\end{array}$ \\
\hline
\end{tabular}

$\mathrm{PBC}=$ performance-based road maintenance contract; DGH $=$ Directorate-General of Highways.

Source: I. Greenwood et al. 2005.

and whether they fulfill the three main objectives: (i) to satisfy road users with respect to accessibility, comfort, travel speed, and safety; (ii) to minimize the total long-term cost to the road organization and road users; and (iii) to minimize environmental impacts.

145. Estimate the likely cost: Based on the road asset conditions, estimates of the works will have to be made to bring the road asset conditions to the required performance levels. In addition, a projection of the deterioration of the road assets over the contract period will have to be made 
and an indicative work program, including any required additional works, needs to be established to estimate the likely cost of the PBC. Making the cost estimate available to tenderers (with little or no PBC experience) may serve as a valuable guideline for their own determination of their tender pricing.

146. Risk assessment and mitigation: Refer to section 2.5 on Risk and Risk Mitigation.

\section{B. Design of Tender Documents}

147. There is a wide variety of tender documents for PBCs available online. ${ }^{49}$ Each country uses its own format and develops it further based on past experience. CAREC countries may refer to the sample bidding documents prepared by the World Bank ${ }^{50}$ or the Department of Transport in the UK, ${ }^{51}$ then adapt these contracts to take into account specific country situation. The ADB contract template for small works may be used and adapted for PBCs for routine maintenance.

148. The following issues should be given special consideration when designing tender documents for PBCs: (i) performance levels, (ii) payment and incentive systems, (iii) performance monitoring, and (iv) risks and risk mitigation (see section 2). Other important issues are the (i) management services, (ii) data collection and management, (iii) cost escalation clause, (iv) traffic volume and overloading adjustment clause, (v) utility services, (vi) payment guarantees and/or bond requirements, and (vii) interest payments for late payment by the client.

149. Management services in PBCs are more complex than in a conventional contract and include a program of performance, which is detailed in Appendix 5. The contractor should establish and maintain, within his own organizational structure, a performance management unit (PMU) staffed with qualified personnel, whose task is to monitor and verify continuously the degree of compliance by the contractor with the service levels. The PMU should also ensure the quality control, inspection, and testing required for all works and services during the contract period. The PMU should maintain at all times detailed and complete data on the condition of the road and related assets included in the contract. It also needs to provide the contractor with all the information needed to manage and maintain the road and related assets in accordance with the performance or service levels. The roles and responsibilities of the PMU will be clearly described in the contractor's program of performance.

150. Data collection and management is the responsibility of the contractor. The road organization needs to make sure that the data collected by the contractor is to a predefined standard and turned over to the road organization. The contract must include proper procedures for the collection and management of data by the contractor.

151. Cost escalation clause: Since PBCs are longer-term contracts, prices will change over time and will have an influence on the actual cost to the contractor. Therefore, the contract needs to include a cost escalation clause that will reflect the different inputs required over the contract period. Price adjustments should be done once a year, or more frequently for countries with high inflation.

152. Traffic volume and overloading adjustment clause: Traffic volume and composition as well as axle loads have a major influence on pavement deterioration and thus need to be forecasted over the contract period. If it is expected that the actual figures may substantially deviate from the forecast, the risk to the contractor may be reduced through a price adjustment formula.

153. Utilities within the road reserve: Although maintenance of utilities is not included in the PBC, the contractor should be made responsible for any damage to utilities. However, the contractor should be given the right to approve backfill quality and compaction by others, since these may require the contractor to make good the repair to maintain the $\mathrm{PBC}$ performance levels.

154. Interest on late payment by client cause additional cost to the contractor. Therefore, an interest charge should be applied to the late payment, based on the standard international borrowing rate, such as London Inter-bank Offered Rate (LIBOR).

Appendix 4 provides a selection of tender documents used in various countries.

50 World Bank. 2006.

51 Government of the United Kingdom, Department for Transport. 2015. 
155. Bond requirements: A two-stage performance bond is recommended: the first stage to cover the initial works, and the second one for the maintenance period. The bond amount should be sufficient to cover any outstanding capital works, any maintenance works to bring the assets up to the required performance levels, and the cost of re-tendering in the event of the contractor defaulting or contract termination due to non-performance of the contractor.

\section{Data Supplied to Tenderers}

156. The following data refer to data supplied to tenderers for maintenance activities only. Data supplied to tenderers for other road works are no different from data supplied for traditional civil work contracts:

- description of project area;

- detailed list of roads and road sections and right of way;

- traffic volume and composition during the last 5 years;

- axle load measurements during the last 5 years, if available;

- rainfall quantities and pattern;

- temperature pattern;

- snow fall pattern for the last 5 years;

- technical information on each road, section such as construction data, previous works executed;

- maintenance history, if available;

- annual routine maintenance expenditures during the last five years per kilometer;

- annual expenditures for winter services;

- road asset inventory;

- road condition data, inclusive of deflection, roughness, skid resistance, and rutting;

- noncommittal indicative work program over the contract period; and

- noncommittal cost estimates.

\section{Supervision arrangements}

157. Supervision management may either be done by the client or by a consultant. If the supervision is done by a client that does not have experience in PBCs, it is recommended that a qualified coaching and training consultant be employed to coach and train the staff of the client as well as the contractor in managing and monitoring the PBC. It is further recommended that any consulting contract include performance levels and management service levels with payment reductions for noncompliance. Sample terms of reference for consultancy contracts can be found on the website of the World Bank. ${ }^{52}$

\subsection{Procure a Performance-Based Road Maintenance Contract Well}

158. Procurement covers (a) prequalification of contractors; (b) organization of pre-bid seminars for prequalified contractors; (c) answering queries and issuing addendums; (d) evaluation of bids; (e) award of contract; (f) preparation of tender documents for supervision and/or coaching and training consultants; (g) preparation of qualification criteria for supervision consultants; (h) preparation of qualification criteria for coaching and training consultants; and (i) award of supervision or coaching and training contract.

\section{A. Prequalification of contractors}

159. The objective of prequalification is to make sure that only sufficiently qualified tenderers will proceed to the full tendering process. This will minimize the cost associated with tender preparation and evaluation. The prequalification criteria for contractors would differ depending on the market characteristics and the complexity of the PBC. If it can be expected that more than five contractors will tender, and there is doubt as to their ability or capacity to undertake the work, prequalification is advised.

160. Sample prequalification criteria ${ }^{53}$ are provided below:

- company financial statement and insurance details,

- track record and relevant experience,

- summary of staff with specific skills and experience relevant to the scope of services,

Footnote 26.

53 I. Greenwood et al. 2005. 
- contractor's ability to demonstrate the implementation of innovative practices,

- details of intended partners and subcontractor and/or consultant proposed for the project, and

- $\quad$ ISO 9001 certification. ${ }^{54}$

161. Candidates for a PBC consultancy should submit the following information:

- professional registration;

- track record and relevant experience;

- summary of staff with specific skills and experience in geometric and pavement design, pavement investigation and maintenance planning, pavement management system, construction and rehabilitation supervision, and reporting against performance criteria; and

- $\quad$ ISO 9001 certification or equivalent.

162. If there is a lack of competition, the prequalification threshold might need to be set lower to encourage participation. To compensate for the lack of qualified candidates, training courses might be considered to improve qualifications before going to the full tender stage. The other option is to provide more intensive coaching and training during the contract period.

\section{B. Organization of pre-bid seminars for prequalified contractors}

163. When contractors do not have sufficient experience with PBCs, pre-bid seminars, including site visits, are very important to make contractors familiar with the demands of the contract requirements. One- or 2 -day seminars have often not been enough to achieve this goal and therefore 3 to 4 days are advised.

\section{Answering queries and issuing addendums}

164. This follows the normal procedures for civil works contracts.

\section{Evaluation of bids}

165. Besides the normal requirements for civil contracts, PBCs require additional management and technical qualifications. The exact qualifications needed depend on the scope of the PBC.

166. Nevertheless, some qualifications and experience are required for all PBCs:

- Experience, knowledge, and understanding of issues relating to preservation and maintenance of the assets covered by the contract, and soundness of technical approach for meeting the performance measures for all of the assets referenced in the contract. This includes

- sufficient experience in road maintenance and winter services, where required. If the contractor does not have the necessary experience or expertise and there are no qualified personal to be found on the market, he may want to hire staff of the road organization. This eventuality needs to be covered within the tender documents to put all tenderers on an equal basis;

- the capability of predicting the deterioration pattern of pavements. If this expertise is not available in-house, it would need to be acquired through subcontracting a qualified consultant. This qualification is less important for contracts with shorter durations.

- Sufficient qualified staff. The contractor must detail the experiences of the following key personnel listed in Table 9.

- A quality management system in accordance with ISO 9001 or equivalent and a quality assurance plan for the execution of the contract detailing how to

54 Contractors are required to establish, document, implement, and maintain a QMS that Identifies processes; illustrates sequences and interactions; identifies criteria and methods to ensure effectiveness; documents resources and information necessary to operate, monitor, measure and analyze the processes; and defines action required to achieve the planned results and continually improve the process. See International Organization for Standards. 2015. ISO 9001. Quality Management System—Requirements. http://www.iso.org/obp/ui/\#iso:std:iso:9001:ed-5:v1:en. 
Table 9: Qualifications of Key Personnel

\begin{tabular}{|c|c|}
\hline Key Personnel & Summary of Functions \\
\hline Road Manager & The representative of the contractor, responsible for managing all activities of the contractor under the contract. \\
\hline Operations Manager & $\begin{array}{l}\text { Responsible for the planning, coordination, and execution of all road maintenance operations, including winter service, } \\
\text { if required. }\end{array}$ \\
\hline Performance Manager & $\begin{array}{l}\text { Responsible for the management of the performance management unit, and for the development and maintenance of } \\
\text { the program of performance }\end{array}$ \\
\hline Chief Engineer & Responsible for all technical and engineering duties connected with the contract \\
\hline Systems Manager & $\begin{array}{l}\text { Responsible for telecommunications, hardware, software, MIS system administration and MPC operations, data entry, } \\
\text { maintenance of information, help desk, MIS training, MIS service levels, and MIS backup and recovery. }\end{array}$ \\
\hline
\end{tabular}

MIS = management information system; MPC = mobile personal computer.

Source: Author.

- identify the quality requirements, especially the performance levels, specific to the contract;

- plan and execute the works to satisfy those requirements;

- inspect and/or test the works to ensure compliance with the quality requirements;

- record and monitor the results as evidence of compliance; and

- ensure the prompt actions taken to correct non-compliance.

- An emergency procedures and contingency plan to ensure the safety of the contractor's personnel and road users in the case of emergency and/or road closure. It should include

- an effective communication and event recording system;

- the name, contact number, and specific duties of the contractor's personnel nominated to respond to an emergency event;

- the contact number of other parties who need to be notified in cases of emergencies;

- detailed response procedures for all emergency events; and

- possible detour routes in the event of road closures.
- a traffic management plan, and

- a health and safety management plan.

167. A two-stage bidding may be appropriate to guarantee a minimum qualification. In the second stage, consider evaluating bids not only on the price but also on management and technical experiences. PBC tenderers must have sufficient experience in road maintenance and winter services, where required.

168. Table 10 illustrates the evaluation criteria and weights that have been applied to evaluate bids for the first PBC in Washington, DC. This table demonstrates that for the evaluation of bids the cost of PBCs might be less importance than in traditional maintenance contracts. Other criteria such as relevant experiences and performances of the contractor and its staff and the proposed approach to the PBC are equally or even more important to guarantee a successful implementation.

\section{E. Award of contract}

169. This follows the usual procedure for civil works contracts. Utmost transparency is recommended in the award process to avoid corrupt and fraudulent practices. 
Table 10: Evaluation Criteria and Weights Applied for the Award of a Performance Contract in Washington, DC

\begin{tabular}{|c|c|c|}
\hline Evaluation Criteria & Description/Components & Weight \\
\hline Technical & $\begin{array}{l}\text { Experience, knowledge and understanding of issues relating to preservation and } \\
\text { maintenance of the assets covered by this contract. Soundness of technical } \\
\text { approach for meeting the performance measures for all the assets referenced in } \\
\text { this contract }\end{array}$ & $20 \%$ \\
\hline \multirow{3}{*}{$\begin{array}{l}\text { Staffing, Quality } \\
\text { Control/Quality } \\
\text { Assurance, } \\
\text { Management }\end{array}$} & Staffing Plan & $5 \%$ \\
\hline & Management Plan & $5 \%$ \\
\hline & Quality Control and/or Quality Assurance Plan & $5 \%$ \\
\hline Past Performance & $\begin{array}{l}\text { The extent to which the prime contractor's and subcontractors' past performance } \\
\text { on similar asset preservation, maintenance, and management contracts } \\
\text { demonstrates a likelihood of successfully performing all of the tasks set forth in } \\
\text { this contract. }\end{array}$ & $15 \%$ \\
\hline Cost & $\begin{array}{l}\text { The extent to which proposed costs are realistic and reflect the likely overall cost } \\
\text { to the government over the term of the contract }\end{array}$ & $50 \%$ \\
\hline
\end{tabular}

Source: G. Zietlow. 2004.

\section{F. Preparation of tender documents for supervision and/or coaching and training consultants}

170. As stated above, it is recommended that such contracts include performance levels, including payment reductions for noncompliance. Sample terms of reference for such contracts can be found on the website of the World Bank. ${ }^{55}$

\section{G. Qualification criteria for supervision consultants}

171. The supervision consultant should submit the following information: ${ }^{56}$

- professional registration;

- track record and relevant experience;

- summary of staff with specific skills and experiences for geometric and pavement design, pavement investigation and maintenance planning, pavement management system, construction and, rehabilitation supervision, reporting against performance criteria and PBC contract development and tendering process;

- ISO 9001 certification or equivalent; and

- at least 5 years of experience in the supervision of PBCs.

\section{H. Qualification criteria for coaching and training consultants}

172. This follows the qualification criteria for supervision consultants, but would require at least 5 years of experience in coaching and training of PBC clients and contractors.

\section{Award supervision or coaching and training contract}

173. This follows the usual procedure for consultancy contracts.

\footnotetext{
55 Footnote 26

56 I. Greenwood et al. 2005.
} 


\subsection{Implement a Performance-Based Road Maintenance Contract Well}

174. Implementing PBCs well requires (a) coaching and training, and (b) monitoring and evaluation.

\section{A. Coaching and training}

175. Coaching and training by an experienced consultant helps the client, contractor and subcontractors to better manage and monitor the PBC. Engaging a coaching and training consultant is strongly recommended, especially during the first year of implementation, with regular inputs to reinforce learning over periodic visits. The scope and intensity of coaching and training depends on the qualifications of the staff of the road organization, contractor, and subcontractors. A PBC operational handbook should be developed reflecting the specific needs of the pilot project, especially for the supervision and monitoring of the performance levels. There are some training programs available online, but the main emphasis should be on-the-job training.

\section{B. Monitoring and evaluation}

176. A PBC unit with qualified staff needs to be established within the road organization to monitor the pilot PBC and to design and implement further development of PBCs in the country. Experience has shown that payment reductions are often not strictly enforced. It is strongly recommended to enforce compliance with service levels from the start of the project. Compliance with service levels is the key characteristic of PBCs and must be assigned due importance. A monitoring and evaluation approach should focus on how well the PBCs is fulfilling its objectives, and offer real-time feedback that can be used to improve implementation. 



\section{Recommended Options for Pilot Performance-Based Road Maintenance Contracts in CAREC Member Countries}

177. This chapter recommends three practical options for implementing pilot PBCs in CAREC member countries. These options can be tailored to prevailing road conditions and cover the chosen scope of works and services, payment options, service levels, delivery mode, and supervision arrangements. For each option, the advantages and disadvantages are discussed. In addition, recommendations are made as to what options of pilot PBCs are less favorable for some CAREC countries at this stage.

\subsection{Option 1: Routine Maintenance for 3 to 4 Years for 100-150 km of Roads}

178. This option refers to $P B C$ for routine maintenance, including winter services (where applicable), for 3 to 4 years covering $100-150 \mathrm{~km}$ of paved roads.

179. Road conditions: Roads need to be in good to fair condition requiring no rehabilitation works. The percentage of roads in good condition should be between $40 \%$ and $60 \%$. This means that, if recently rehabilitated road sections are included, there should be enough road sections in fair conditions to provide sufficient pavement works like pothole patching and crack sealing on a continued basis to provide a fairly constant workload to the contractor.

180. Scope: Routine maintenance, winter services (if required), and initial works to bring the road to the required service levels, and the provision of management services. Initial works shall be no more than $40 \%$ of the total contract amount.

181. Payments: Most of the routine maintenance and the initial works shall be paid in a lump sum basis. This requires a detailed indicative work program with cost estimates to be put together by the consultant who prepares the contract. Risk items, for which it is difficult to estimate the quantities needed over the contract period, might be paid on a unit price basis. Winter maintenance might be considered a risk item as winter weather conditions can be highly variable from year to year. For short contracts, this may pose a severe risk to contractors, which they might price into their offers. One option would be to fix a lump sum but with an adjustment formula to account for different winter condition severities. Emergency works also need to be reimbursed on a unit price basis. ${ }^{57}$

182. Service levels: Service levels should be set at a reasonable and affordable level and should be enforced after the completion of the initial works, except for safety relevant service levels and management services, which need to be maintained from the beginning of the contract. Road roughness and deflection may not be used as service levels, if this is too risky for the contractor. Daily road patrolling shall be included in the scope of services.

183. Delivery: Except for countries that have private road maintenance contractors, contracts shall be awarded directly to the road maintenance teams of the road organization working on the selected road network. They would be required to form a private company and may need to incorporate additional expertise for the operation of a company, such as personnel management, accounting

57 Most CAREC countries have a schedule of prices for maintenance activities. If these are not available, a study needs to be undertaken to establish a price schedule. 
and project management, and more specific requirements for road maintenance like work planning, quality assurance and performance monitoring. Contractors should not be required to operate a pavement management system due to the short duration of the contract. An indicative work program would need to be prepared.

184. Most of the required equipment might have to be leased from the road organization since the contract period would be too short to justify investment in expensive equipment. An alternative would be to involve local private road construction companies that would need to acquire the necessary expertise for road maintenance and winter services by hiring, on a permanent or temporary basis, road maintenance staff from the road organization. This would allow competitive local bidding. In both cases, there would be a lack of experience in performance-based road maintenance, which needs to be compensated by a PBC coaching and training consultant.

185. In countries like Pakistan and Afghanistan, which have private road maintenance contractors, competitive local bidding is recommended. Besides the normal requirements for civil works, contractors need to have experience in road maintenance, winter maintenance (if required), and basic management experience related to works programs, reporting, quality assurance system, health and safety management plans, environmental management plan, emergency procedures and contingency plan, traffic management plan, inventory database management, inspections, and management information systems.

186. Most likely, contractors will need to supplement their expertise by hiring experienced consultants. The experience level of these management services needs consideration in the context of the contract duration and local market conditions. Therefore, the hurdle for management services experience should not be set too high to encourage participation and allow for sufficient competition. It is strongly recommended that a coaching and training consultant be on board to assist the road administration as well as the contractor.

187. Supervision: Supervision of the PBC can be by the road organization, but it would require assistance by a PBC coaching and training consultant. The same PBC coaching and training consultant could assist the road organization as well as the contractor.

\subsection{Option 2: Routine and Periodic Maintenance for 5 to 6 Years for $150-200 \mathrm{~km}$ of Roads}

188. This option uses PBC for routine and periodic maintenance, including winter services (where applicable), for a duration of 5 to 6 years covering $150-250 \mathrm{~km}$ of paved roads.

189. Road conditions: Roads need to be in good to fair condition requiring no major rehabilitation.

190. Scope: Routine maintenance, winter services and initial works, including limited rehabilitation and resurfacing works to bring the road to the required service levels. Initial works should not exceed $50 \%$ of the total contract price. The scope would also include management services, road patrolling and the construction and operation of weigh bridges. Depending on the expected pavement deterioration pattern, it might be necessary to program resurfacing works during the contract period.

191. Payments: Management services, routine maintenance and the initial works, including the construction of weigh bridges, should be paid in a lump sum basis. Risk items, where it is difficult to estimate the quantities needed over the contract period, may be paid on a unit price basis. With the longer contract duration, winter maintenance (where required) may be paid on a lump sum basis, since variable winter weather conditions will average out over a longer period. Emergency works need to be reimbursed on a unit price basis. If resurfacing works are required during the contract period, they should be programmed in advance so that tenderers can price the respective years on a lump sum basis.

192. Service levels: Service levels should be set at a reasonable and affordable level and should be enforced after the completion of the initial works, except for safety relevant service levels and management services that need to be maintained from the beginning of the contract. Road roughness and deflection need not be used as service levels, if this is too risky for the contractor. Daily road patrolling should be included in the scope of services.

193. Delivery: Delivery should be done through local competitive bidding. Since road contractors in most of 
the CAREC countries do not have experience in road maintenance, winter services and PBCs, they would need to hire experienced maintenance staff from the existing road organizations and recruit qualified PBC consultants to provide the specific management expertise required for PBCs. Expertise in pavement management systems would not be required due to the relatively short contract period.

194. Supervision: Supervision of the PBC may be by the road organization, but it would require assistance by a PBC coaching and training consultant.

\subsection{Option 3: Routine and Periodic Maintenance for up to 10 Years for 700-1,000 km of Roads}

195. This option pertains to use of PBC for routine and periodic maintenance for the duration of up to 10 years and for an extended road network of $700-1,000 \mathrm{~km}$. This option reflects the concept of the planned performancebased road maintenance project in Kazakhstan, which is more comprehensive since it includes institutional and regulatory reforms and capacity building.

196. Road conditions: Road conditions need to be good to fair, requiring no major rehabilitation within the contract period.

197. Scope: Routine maintenance and winter services (if required) and initial works to bring up the road to the required service levels. Initial works should not amount to more than $40 \%$ of the total contract amount. The scope would also include management services, the construction and operation of weighbridges, emergency works, and patrolling services. In addition, the contractor would need to assist the road organization with their institutional and regulatory reforms and capacity building.

198. Payments: All maintenance works and winter services will be paid on a lump sum basis. Initial works to bring the road to the required service levels and the construction and operation of weigh bridges will also be paid on a lump sum basis. Only emergency works will be paid on a unit price basis.

199. Service levels: Service levels should be set at a reasonable and affordable level and should be enforced after completion of the initial works, which might take from 1 to 1.5 years. During this time, only safety-relevant service levels and winter maintenance and management service levels will need to be enforced. Road roughness and deflection need not be used as service levels, if this is too risky for the contractor.

200. Delivery: The PBC will be contracted to a management contractor based on international bidding. The contractor will manage the inputs (equipment, vehicles, personnel, storage facilities) from the road organization for the maintenance works and winter services. Additional equipment need to be purchased. Initial works will be contracted out with the private sector road construction companies.

201. Supervision: For project supervision, an independent international consultant experienced in institutional development as well as performance-based road maintenance shall be employed.

\subsection{Comparison of Performance-Based Road Maintenance Contract Options}

202. Each of the three options above has their respective advantages and disadvantages, which do not necessarily apply to all countries equally.

203. The advantage of the first option is that it creates private road maintenance contractors who will learn how to maintain roads more effectively and efficiently. This will have a good demonstration effect. By gradually extending the concept to more roads, additional private road maintenance contractors will be developed who eventually will compete against each other to create the competitive environment that is necessary to reap the full benefits of PBCs. At the same time, the institutional, regulatory, financial, and technical framework needs to be developed to guarantee sustainability. This might need to be accomplished by a separate technical assistance project.

204. Another advantage of this option is that, due to the short contract duration, the risks to the contractor are limited. There is the risk that government employees might not want to join private companies due to the risk that the contracts might not get prolonged, leaving them without 
employment. A firm commitment by the government to continue with contracting out road maintenance to the private sector or a guarantee to these employees that they could return to the road organization if contracts to the private sector will be discontinued could mitigate this problem. Such guarantee was once given to employees of the road administration in Uruguay to incentivize them to form own companies. This option would require sufficient kilometers of roads with a good mix of good and fair conditions, which might be difficult to find. At the beginning, there might be limited creation of value for money due to limited competition but this will most likely improve over time.

205. The second option has a better potential to create value for money immediately, since there will be competition between contractors. The other advantage is that the contractor has a clear incentive to deliver better quality initial works as they need to maintain the road for another 5 years. The incentive would be even higher the longer the contract period, but the IFIs might not want to finance projects with duration of more than 6 years. In this case local funding would need to fill the financial gap. The main risk is that there might not be enough qualified contractors, or enough staff familiar with road maintenance and winter services to join local road contractors, and there might not be enough consultants to assist contractors to prepare the tender offer as well as to assist them during implementation.

206. This can be partially mitigated by an indicative work program for the entire contract period, including noncommittal cost estimates to be prepared by the project preparatory technical assistance consultant and by coaching and training of the contractor during the contract period. The main focus should be to develop the local contracting and consulting industry. If foreign contractors are allowed to bid for the PBC, it is recommended that at least $85 \%$ of the works and services should be undertaken by local contractors and consultants, and the contractor should have a clear obligation to train and prepare local staff and subcontractors to bid for PBCs in the future.
This should be made part of the management obligations and measured on the basis of service levels, with payment reductions for noncompliance.

207. The advantage of the third option is that it includes the required institutional and regulatory reforms and capacity building. Although it requires an international contractor well experienced in institutional reforms and performance-based contracts, all works and services will be either subcontracted or performed by the existing road maintenance staff. This option will not create private PBC contractors but will enable the state-owned road maintenance contractor to manage PBCs in the future. The privatization of the state-owned road maintenance contractor would have to be done at a later stage to create competition and to reap the full benefit of PBCs. There is a risk associated with finding a sufficiently qualified management contractor, or that the government might not pursue the required reforms.

208. There are other options of pilot PBCs, which are less recommended for most of the CAREC countries at this stage. These are discussed below:

- PBCs with capital works of more than $40 \%$ of the total contract amount should be avoided since they attract contractors, which are mainly interested only in the capital works and may not give sufficient attention to the performancebased maintenance works and services aspect. In this case, it might be better to contract these works under conventional civil works contracts.

- Pilot PBCs with more than 10 years seem too risky considering the difficult institutional and business difficult environment of most of CAREC member countries at this stage.

- Pilot projects for community-based road maintenance are also not recommended at this stage since they require a stable flow of funds, which does not seem to be guaranteed in most of the CAREC countries. 


\section{Role of International Financial Institutions}

209. While developed countries do not require financial assistance in implementing PBCs, developing and transitional countries may need the help of international financial institutions (IFIs). Despite their importance, roads in many developing and transitional countries are still underfinanced, poorly managed, and badly maintained. Normally, only $20 \%-40 \%$ of the amounts required are spent on routine and periodic maintenance, and 33\% of the main road networks are good, $33 \%$ are in regular condition, and 33\% are in poor condition. This was true 35 years ago, ${ }^{58}$ the situation has barely changed despite heavy investments made by countries and IFIs.

210. Most funding went to road construction and rehabilitation. New construction or major rehabilitation works may not always be justified on an economic basis. Typical rates of returns are 10\% for new construction, $20 \%$ and $40 \%$ for rehabilitation works, and $50 \%$ and $100 \%$ for routine and periodic maintenance. By failing to commit their scarce resources to road maintenance, which produce the highest economic rate of return, countries are unconsciously taking action to weaken their economies. Not spending enough to maintain existing road assets results in higher future expenditure and imposes additional costs on road users. Therefore, routine and periodic maintenance should take precedence over any major rehabilitation or new construction works.

211. This requires a major shift in investment policies in the CAREC member countries. IFls can assist governments in undertaking the required policy shift by attaching a high priority to financing road maintenance works. IFls can play a major role in assisting CAREC member countries to implement PBCs by financing consultancy services including awareness seminars, training programs, feasibility and implementation studies, project preparation, supervision and coaching and training services. These consulting services can be designed to support the successful implementation of tailored works and services for pilot PBC projects.

212. In addition, PBCs may form part of IFI-financed innovative road asset management programs, which need a long-term engagement by IFIs that goes beyond the normal project cycle. Such programs require a major a cultural shift, institutional reforms, and human resource development which may well take decades, well beyond the usual IFI project duration.

58 World Bank. 1988; and Heggie and Vickers. 1998. 



\section{References}

ADB. 2011. Community-Based Routine Maintenance of Roads by Women's Groups. Manila. http://www. adb.org/sites/default/files/publication/28942/ guideroad-maintenance-womens-groups.pdf

2015. Completion Report: Stocktaking of Road Maintenance in Central and West Asia. Stocktaking of Pilot Performance Based Road Maintenance Contracts in Tajikistan. Manila.

2017. Reports and Recommendation of the President to the Board of Directors: Proposed Loan and Administration of Loan Georgia: Batumi Bypass Road Project. Manila (Project Number: 50064-001).

S. Burningham and N. Stankevich. 2005. Why Maintenance Is Important and How to Get It Done. World Bank Transport Note. No. TRN4. Washington, DC: The World Bank. https:// siteresources.worldbank.org/INTTRANSPORT/ Resources/336291-1227561426235/5611053 -1231943 010251/TRN4_Road_Maintenance.pdf

Carl Bro Intelligent Solutions. 2006. Review PMMR/ PBC Experiences in the Philippines. National Road Improvement and Management Program. Manila.

European Bank. 2016. Policy Challenges in the Implementation of Performance-based Contracting for Road Maintenance. https://library.pppknowledgelab. org/documents/4360? ref_site=kl

M. Frost and C. Lithgow. 1996. Improving Quality and Cutting Cost through Performance Contracts Australian Experience. Presented during the Road Management Training Seminar in Washington, DC, USA. 17 - 18 December. http://www.zietlow. com/docs/frost.htm ${ }^{1}$
Government of New Zealand, Transit New Zealand. 2004. Risk Management Process Manual. Wellington. https://www.nzta.govt.nz/assets/ resources/risk-management-process-manual/ docs/risk-management-process-manual.pdf

Government of New Zealand, Transport Agency. 2014. State Highway Procurement Strategy 2014. New Zealand. https://www.nzta.govt.nz/assets/ resources/state-highway-portfolio-procurementstrategy/docs/sh-procurement-strategy-2014.pdf

Government of India, State of Punjab, Public Works Department (Buildings and Roads). 2011. Bidding Documents for Procurement of Contract under Output and Performance Based Contract (OPRC) (Asset Management Contract) for Improvement, Rehabilitation, Resurfacing and Routine Maintenance Work of Roads of Sangrur-MansaBathinda Contract Area. Punjab. http://www.prbdb. gov.in/files/oprc/OPRC\%20final.pdf

Government of the United Kingdom, Department for Transport. 2015. The Form of Contract for Highway Maintenance Services - Notes for Guidance. Ver. 2. http://www.highwaysefficiency. org.uk/asset/20517D1F-8D74-4F9AA4FB4BC1DA3A77A0.E179C881-316B-4C2B8801DD6AD253D3FC

I. Greenwood et al. 2005. Introducing Performance Based Maintenance Contracts to Indonesia Framework Document. Washington, DC: The World Bank. http://documents.worldbank.org/curated/ en/352401468269092824/Framework-forintroducing-performance-based-maintenancecontracts-to-Indonesia 
I. Heggie and P. Vickers. 1998. Commercial Management and Financing of Roads. World Bank Technical Paper Africa Series. No. 275. Washington, DC: The World Bank. http://www.ssatp.org/sites/ssatp/files/publications/ WorldBank-TechnicalPapers/TP275/TP275.pdf

W. Hymen. 2009. Performance-Based Contracting for Maintenance: A Synthesis of Highway Practices. Washington, DC: Transport Research Board of the National Academies. http://onlinepubs.trb.org/ onlinepubs/nchrp/nchrp_syn_389.pdf

International Organization for Standards. 2015. ISO 9001. Quality Management System-Requirements. http:// www.iso.org/obp/ui/\#iso:std:iso:9001:ed-5:v1:en

K. Lande. 1999. Privatized Highway Asset Management Management of Subcontract Maintenance. Paper prepared for the Symposium on Innovative Financing of Transport Projects. 29 September-1 October. Ha Noi. http://www.zietlow.com/docs/vms1_00a.htm

OPUS. 2012. Review of Delivery Models for Works and Services. New Zealand. https://www.nzta.govt. nz/assets/resources/rmtf-report/docs-interim/ delivery-models-report.pdf

P. Pakkala et al. 2007. International Overview of Innovative Contracting Practices for Roads. Helsinki: Finnish Road Administration. https://julkaisut. liikennevirasto.fi/pdf/internoverview.pdf

N. Radovic et al. 2014. Output and Performance Based Road Maintenance Contracting-Case Study Serbia. Technical Gazette. No. 21. http://www. hrcak.srce.hr/file/182234

Smart Growth America. 2014. Repair Priorities: Transport Spending Strategies to Save Taxpayer Dollars and Improve Roads. http://www.smartgrowthamerica. org/documents/repair-priorities-2014.pdf

G. Williams. 2008. Case Study. Afghanistan, KabulJalalabad Road Maintenance. Arusha.

World Bank. 1988. Road Deterioration in Developing Countries-Causes and Remedies. Washington, DC. http://documents.worldbank.org/curated/ en/722851468162562433/pdf/multi-page.pdf
2006. Sample Bidding Documents - Procurement of Works and Services under Output- and Performance - based Road Contracts and Sample Specifications. Washington, DC. http://siteresources. worldbank.org/INTPROCUREMENT/ Resources/278019-1160588240300/OPRC-1006.pdf

2008. Team-Based Routine Maintenance of Rural Roads-Managerial Manual for Routine Road Maintenance Teams. http://www.cartier. dds.nl/china/cdrom/pdfen/Team-based\%20 routine $\% 20$ maintenance $\% 20$ of $\% 2$ rural $\% 20$ roads $\% 20-\% 20$ Technical\%20Manual\%20for\%20 Maintenance\%20Teams\%20-\%20EN.pdf ${ }^{2}$

2009. Resource Guide: Performance-Based Contracting for Preservation and Improvement of Road Assets. http://www-esd.worldbank.org/pbc_ resource_guide/index.html

2014a. Review of Performance Based Contracting in the Road Sector-Phase 1. World Bank Transport Note. No. TP-42A. Washington, DC. https:// openknowledge.worldbank.org/bitstream/handle/1 0986/18648/878260NWPOTP4200Box377314B OOPUBLICO.pdf? sequence $=1$

2014b. A Guide to Deliver Good Asset Management in the Road Sector through Performance Contracting. World Bank Transport Note No. TP-42. https://openknowledge. worldbank.org/bitstream/handle/10986/18646/8 78270NWPOTP4200Box377314B00PUBLIC0. pdf? sequence $=1$

2017. Georgia - Second Secondary and Local Roads Project (SLRP II) : P122204 - Implementation Status Results Report: Sequence 09 (English). http://documents.worldbank.org/curated/ en/130491492544799575/Georgia-SecondSecondary-and-Local-Roads-Project-SLRPII-P122204-Implementation-Status-ResultsReport-Sequence-09

USAID. 2012. Final Report. Task Order No. 14. Road Operation and Maintenance Program Final Performance Evaluation. http://pdf.usaid.gov/pdf _ docs/pdacu415.pdf 
G. Zietlow. 2004. Implementing Performance-based Road Management and Maintenance Contracts in Developing Countries. An Instrument of German Technical Cooperation. Eschborn: German Development Cooperation. http://www.zietlow. com/docs/PBMMC-GTZ.pdf

2005. Using Microenterprises to Create Local Contracting Capacity-The Latin American Experience in Road Maintenance. University of Birmingham, Birmingham. April. http:// www.zietlow.com/docs/Using\%20MicroEnterprises-05.pdf

2006. Performance-Based Management and Maintenance of Roads. Case Study 2: Uruguay. Washington, DC: World Bank. http://www-esd. worldbank.org/pbc_resource_guide/Docslatest\%20edition/cases-and-pdfs/5_PBC_ Uruguay.pdf
2009. Performance-based Management and Maintenance of Roads (PMMR). Presentation. University of Birmingham. http://www. performance-based-road-contracts.com/pres/ Birmingham2009.ppt

2011. Output and Performance-Based Road Contracts. Presentation. London: European Bank for Reconstruction. May. http://www.performancebased-road-contracts.com/pres/EBRD.OPRC.pptx

2015. Road Asset Management and Performance Based Contracts. Presentation. Manila: ADB. 29 July. https://de.scribd.com/doc/279677448/ Performance-Based-Contracts-PBCs-for-RoadMaintenance-From-Concept-to-Practice 



\section{Appendix 1: Different Types of Performance-Based Road Maintenance Contracts}

\begin{tabular}{|c|c|c|c|}
\hline Type of PBC & \multicolumn{2}{|c|}{ Characteristics } & Comments \\
\hline \multirow[b]{2}{*}{$\begin{array}{l}\text { PBCs that require major } \\
\text { capital works (initial } \\
\text { rehabilitation and periodic } \\
\text { works): more than } 30 \% \text { of } \\
\text { the total contract price, } \\
\text { besides routine maintenance } \\
\text { and winter maintenance (if } \\
\text { required). } \\
\text { This contract type is mainly } \\
\text { used in developing countries } \\
\text { due to the poor road } \\
\text { conditions. } \\
\text { Also known as Ouput- and } \\
\text { Performance-Based Road } \\
\text { Contracts or Rehabilitation } \\
\text { and Maintenance Contract }\end{array}$} & Duration & Payments & \multirow{2}{*}{$\begin{array}{l}\text { Contracts with less than } \\
5 \text { years should be avoided } \\
\text { since they tend to attract } \\
\text { contractors that are only } \\
\text { interested in the capital } \\
\text { works. It is recommended that } \\
\text { contracts have a duration of } \\
\text { at least } 8 \text { years so that clients } \\
\text { can reap the benefits of PBCs } \\
\text { such as better incentives to } \\
\text { deliver good quality works, } \\
\text { introduction of innovative } \\
\text { solutions, and minimized } \\
\text { costs. }\end{array}$} \\
\hline & $\begin{array}{l}5-10 \text { years for paved roads } \\
4-5 \text { years for unpaved roads }\end{array}$ & $\begin{array}{l}\text { Performance basis for routine } \\
\text { and winter maintenance and } \\
\text { lump sum basis for capital } \\
\text { works. In some cases, capital } \\
\text { works or even some routine } \\
\text { and winter maintenance } \\
\text { activities are paid on a unit } \\
\text { price basis to minimize risks to } \\
\text { contractors. }\end{array}$ & \\
\hline $\begin{array}{l}\text { PBCs that require no or little } \\
\text { initial works to bring roads to } \\
\text { the required service levels, } \\
\text { besides routine maintenance } \\
\text { and winter maintenance } \\
\text { (if required), and periodic } \\
\text { maintenance. } \\
\text { This contract type is also } \\
\text { referred to as Network } \\
\text { Management PBCs, } \\
\text { Performance Specified } \\
\text { Road Maintenance } \\
\text { Contract or Performance- } \\
\text { based Management and } \\
\text { Maintenance of Roads }\end{array}$ & $3-10$ years & $\begin{array}{l}\text { Performance basis for routine } \\
\text { and winter maintenance and } \\
\text { lump sum basis for capital } \\
\text { works. In some cases, capital } \\
\text { works or even some routine } \\
\text { and winter maintenance } \\
\text { activities are paid on a unit } \\
\text { price basis to minimize risks to } \\
\text { contractors. }\end{array}$ & $\begin{array}{l}\text { Such contracts require good } \\
\text { to fair road conditions which } \\
\text { are more found in developed } \\
\text { countries. Shorter term } \\
\text { contracts are mainly used to } \\
\text { gain experience with PBCs and } \\
\text { increase in duration over time. }\end{array}$ \\
\hline $\begin{array}{l}\text { PBCs for routine and winter } \\
\text { maintenance (if required). } \\
\text { This contract type is also } \\
\text { known as Service Level } \\
\text { Maintenance Contract. }\end{array}$ & $\begin{array}{l}1-8 \text { years } \\
\text { In Malaysia, contract } \\
\text { duration was } 15 \text { years, with } \\
\text { renegotiation of price every } \\
5 \text { years. }\end{array}$ & $\begin{array}{l}\text { Mainly on a performance } \\
\text { basis. }\end{array}$ & $\begin{array}{l}\text { Contracts require good to fair } \\
\text { road conditions that are more } \\
\text { found in developed countries. } \\
\text { Shorter term contracts are } \\
\text { mainly used to gain experience } \\
\text { with PBCs and increase in } \\
\text { duration over time. }\end{array}$ \\
\hline
\end{tabular}


Appendix 1 continued

\begin{tabular}{|c|c|c|c|}
\hline Type of PBC & \multicolumn{2}{|c|}{ Characteristics } & Comments \\
\hline $\begin{array}{l}\text { Simple PBCs for } \\
\text { routine maintenance on } \\
\text { unpaved roads. } \\
\text { This contract type is known } \\
\text { as Community-Based } \\
\text { Maintenance Contract. }\end{array}$ & $1-3$ years & $20-40 \mathrm{~km}$ & $\begin{array}{l}\text { Mainly used on provincial and } \\
\text { rural road networks and in } \\
\text { some cases on main roads as } \\
\text { well. Works are executed by } \\
\text { community based groups or } \\
\text { small local enterprises. }\end{array}$ \\
\hline
\end{tabular}

$\mathrm{km}=$ kilometer PBC = performance-based road maintenance contracts.

Source: Author. 


\section{Appendix 2: Framework for the Analysis of Capacities of Road Organizations, Contractors, and Consultants}

The main capacities to be analyzed for the road organization, contractors and consultants are as follows:

- number and qualification of staff to implement performance-based road maintenance contracts (PBCs),

- sufficient relevant physical resources of the contractor,

- experience in road maintenance management,

- experience in road maintenance activities,

- experience in road rehabilitation and improvement works,

- experience in long term contracts,

- quality assurance capabilities of contractors and consultants (ISO 9001 or equivalent),

- experience in project management,

- pavement management system experience,

- data collection and analysis experience, and

- experience in business risk processes.

Deficiencies would need to be identified and an assessment would need to determine additional measures that can be taken to improve capacity through training.

An example of a framework for assessing the capacity of the government, contractors and consultants is illustrated in Table A2. This assessment is important to develop an implementation strategy for pilot PBCs.

Table A2: Framework for Assessing the Capacity of the Government, Contractors, and Consultants in Performance-Based Road Maintenance Contracts

\begin{tabular}{|c|c|c|c|c|c|c|c|c|c|}
\hline \multirow[b]{2}{*}{ Area } & \multicolumn{3}{|c|}{ People's Republic of China } & \multicolumn{3}{|c|}{ Egypt } & \multicolumn{3}{|c|}{ Indonesia } \\
\hline & 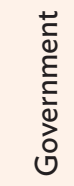 & 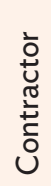 & 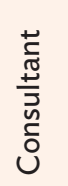 & 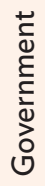 & 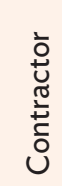 & 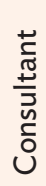 & 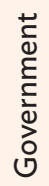 & 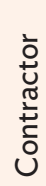 & 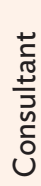 \\
\hline \multicolumn{10}{|l|}{ Staff Resources } \\
\hline \multicolumn{10}{|l|}{ Physical Resources } \\
\hline \multicolumn{10}{|c|}{ Maintenance Management } \\
\hline Maintenance Activities & & & & & & & & & \\
\hline
\end{tabular}


Table A2 continued

\begin{tabular}{|c|c|c|c|c|c|c|c|c|c|}
\hline \multirow[b]{2}{*}{ Area } & \multicolumn{3}{|c|}{ People's Republic of China } & \multicolumn{3}{|c|}{ Egypt } & \multicolumn{3}{|c|}{ Indonesia } \\
\hline & 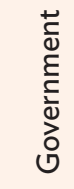 & 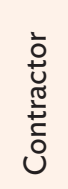 & 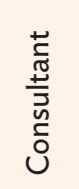 & 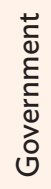 & 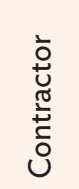 & 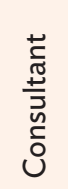 & 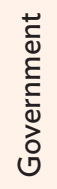 & 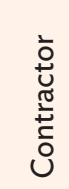 & 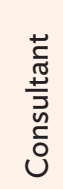 \\
\hline \multicolumn{10}{|l|}{ Quality Assurance } \\
\hline \multicolumn{10}{|c|}{$\begin{array}{l}\text { Pavement Performance and } \\
\text { Understanding }\end{array}$} \\
\hline \multicolumn{10}{|l|}{ Project Management } \\
\hline \multicolumn{10}{|c|}{$\begin{array}{l}\text { Project Management Staff } \\
\text { Experience }\end{array}$} \\
\hline \multicolumn{10}{|c|}{ Data Collection and Analysis } \\
\hline \multicolumn{10}{|c|}{$\begin{array}{l}\text { Tender Document and } \\
\text { Development }\end{array}$} \\
\hline \multicolumn{10}{|l|}{ Partnering Experience } \\
\hline \multicolumn{10}{|c|}{ Business Risk Processes } \\
\hline Legislative Capacity & & $\mathrm{N} / \mathrm{A}$ & $\mathrm{N} / \mathrm{A}$ & & $\mathrm{N} / \mathrm{A}$ & $\mathrm{N} / \mathrm{A}$ & & $\mathrm{N} / \mathrm{A}$ & $\mathrm{N} / \mathrm{A}$ \\
\hline
\end{tabular}

Moderate to sufficient capability

Limited capability

No capability

N/A Not applicable

Source: C. R. Bennett. 2007. Framework for Introducing Performance Based Maintenance Contracts. Presentation. The World Bank. 


\section{Appendix 3: Sample List of Bidding Documents}

A number of bidding documents are available online.

- World Bank. 2006. Sample Bidding Documents: Procurement of Works and Services under Output and Performance Based Road Contracts and Sample Specifications. https://www.google. de/?gws_rd=ssl\#q=sample+bidding+documents +oprc+world+bank

- Government of India, Punjab State. 2011. Bidding Documents for Procurement of Contract under Output and Performance Based Contract (OPRC) (Asset Management Contract) for Improvement, Rehabilitation, Resurfacing and Routine Maintenance Work of Roads. Punjab, India. http:// prbdb.gov.in/files/oprc/OPRC\%20final.pdf

- Government of India, Bihar State. Bidding Documents. http://rcd.bih.nic.in/MBD/CMBD28-02-2014.pdf

- Highways Efficiency Maintenance Program. 2015. The HMEP: Standard Form of Contract for Highway Maintenance. http://www. highwaysefficiency.org.uk/efficiency-resources/ procurement-contracting-and-standardisation/ the-hmep-standard-form-of-contractforhighway.html

For bidding documents for Cambodia, Canada, Madagascar, New Zealand, Serbia and Montenegro, Tanzania, and Washington, DC, see The World Bank. 2009. Resource Guide: Performance-Based Contracting for Preservation and Improvement of Road Assets. http://www-esd.worldbank.org/pbc_resource_guide/ BiddingDocs.htm
For bidding documents for Argentina, Australia, New Zealand, and Peru refer to: The World Bank. 2009. Resource Guide: Performance-Based Contracting for Preservation and Improvement of Road Assets. http://www-esd.worldbank.org/pbc_resource_guide/ ContractDocs.htm

For bidding documents of New Zealand performancebased road maintenance contracts, see:

- New Performance Contract Model: Outcome Maintenance Contract (OMOC) Conditions of Contract. https://www.nzta.govt.nz/assets/ consultation/mo-review/docs/omoc-conditionsof-contract.pdf

- Maintenance Specifications. https://www.nzta. govt.nz/assets/consultation/mo-review/docs/ omoc-maintenance-specification.pdf

- Further Documents related to OMOC can be found at the New Zealand Transport Agency website: https://www.nzta.govt.nz/ searchresults?term $=$ omoc

- State Highway Maintenance Contract Proforma Manual 2015. https://www.nzta.govt. $\mathrm{nz} /$ resources/state-highway-maintenancecontract-proforma-manual/maintenancecontract-proforma.html

- State Highway Maintenance Contract Proforma Manual 2006. http://www-esd.worldbank. org/pbc_resource_guide/Docs-latest $\% 20$ edition/bidding\%20docs/new\%20zealand/ ManualSection180_FileName.pdf 


\section{Appendix 4: List of Online Documents and Presentations on Performance-Based Road Maintenance Contracts}

On terms of reference for consulting services:

- The World Bank. 2009. Resource Guide: Performance-Based Contracting for Preservation and Improvement of Road Assets. http://wwwesd.worldbank.org/pbc_resource_guide/TOR. htm

On performance-based road maintenance contracts training material:

- The World Bank. 2009. Resource Guide: Performance-Based Contracting for Preservation and Improvement of Road Assets. http:// www-esd.worldbank.org/pbc_resource_guide/ TrainingMaterial.htm

On implementing performance-based maintenance contracts in Central Asia Regional Economic Cooperation Program countries, refer to the presentations made during the First Training in Implementing Performance-Based
Maintenance Contracts held in Beijing, People's Republic of China, 27-29 November 2012, available at http:// www.carecprogram.org/index.php?page=first-trainingin-implementing-performance-based-maintenancecontracts

Other references include:

- National Academies of Sciences, Engineering, and Medicine. 2009. Performance-Based Contracting for Maintenance. Washington, DC: The National Academies Press. https://doi.org/10.17226/14266. http://www.nap.edu/catalog/14266/nchrpsynthesis-389-performance-based-contractingfor-maintenance

- Government of the United States, Nevada Department of Transportation. 2015. Investigation of an Innovative Maintenance Contracting Strategy: The Performance-Based Maintenance Contract (PBMC). http://epubs.nsla.nv.gov/ statepubs/epubs/31428003067119.pdf 


\section{Appendix 5: Management Services}

This section has been adapted from The World Bank's study on Performance-Based Road Contracts and Sample Specifications. ${ }^{1}$

Management services include the establishment and operation of the performance management unit described above, the communication system, site regulations, program of performance, inspection system, and reporting. Special emphasis is given to the program of performance, which is described in detail. The program of performance embraces the work programs, the operational plan, the winter services operational plan, the quality assurance plan, the health and safety management plan, environmental management plan, the risk management plan, and the information management plan.

\section{Work Program}

First Quarter Work Program. This program shall detail the location, extent and timing of all services and works the contractor proposes to undertake during the first three months of the contract, together with the resources of personnel, equipment and materials that will be employed. The program shall be submitted to the project manager for consideration and approval no later than the start date.

Annual Work Program. The annual work program shall detail the location, extent and timing of all works that the contractor proposes to complete during the next calendar year together with the resources of personnel, equipment and materials that will be employed. For the initial year or part-year of the contract, depending upon the start date, a work program for the remainder of the first calendar year shall be submitted to the project manager for consideration and approval no later than 1 month after the start date. For subsequent calendar years, the annual work program shall be submitted to the project manager for consideration and approval no later than 1 month before the commencement of each calendar year.

\section{Operational Plan}

The operational plan shall describe how the contractor will undertake the services (excluding winter service) to achieve the operational service levels, including but not limited to the following matters:

- organizational structure for management and delivery of the services;

- locations and coverage of, depots and storage facilities;

- numbers, classification and deployment of equipment and personnel;

- provisions for procurement and storage of materials;

- arrangements for meteorological data collection and weather forecasting;

- procedures for safety inspections and service level inspections;

- procedures for structural inspections;

- procedures for routine maintenance and repair works;

- $\quad$ procedures for incident response and emergency works;

- procedures for response to third party enquiries, reports and complaints; and

World Bank. 2006. Sample Bidding Documents - Procurement of Works and Services under Output- and Performance -based Road Contracts and Sample Specifications. Washington, DC. http://siteresources. worldbank.org/INTPROCUREMENT/Resources/278019-1160588240300/OPRC-10-06.pdf 
- procedures for entering and maintaining accurate and timely data in the MIS.

\section{Winter Service Operational Plan}

In addition to the above, the winter service operational plan shall describe how the contractor will undertake the winter service to achieve the operational service levels, including, but not limited to the following matters:

- organizational structure for management and delivery of the winter service;

- locations and coverage of winter service stations, depots and storage facilities;

- design and location of snow protection measures including: snow isolating, snow diverting, snow capturing and snow detaining structures-either permanent or temporary;

- provision and deployment of snow poles to mark the road edges during severe weather;

- numbers, classification and disposition of winter service equipment and personnel;

- provisions for procurement, disposition and storage of salt and other de-icing materials;

- arrangements for meteorological data collection and weather forecasting;

- work plans for each defined weather and road condition;

- procedures for supervision and control of performance of winter service;

- approach to and methods of measuring and recording skidding resistance achieved during winter service operations (as a minimum, one measurement each minute by each snow plough/ gritter or similar vehicle);

- procedures to be adopted when for its own safety traffic has to be restricted or closed for some types of vehicles and logistics for implementation of restrictions;

- readiness levels for each defined weather and road condition, including: resource availability and deployment; contingency planning; monitoring and reporting;

- developing and applying procedures to guarantee the required skid resistance during winter conditions; and
- methods of dissemination of information on the condition and passability of roads.

\section{Quality Assurance Plan}

The purpose of the quality assurance plan is to integrate the requirements of the contract and the quality assurance systems to deliver the services. The quality assurance plan describes the methods and procedures, which the contractor will apply for the execution of the contract, including how the contractor will:

(a) identify the quality requirements specific to the contract;

(b) plan and execute the services and works to satisfy those requirements;

(c) inspect and/or test work and materials to ensure compliance with the quality requirements;

(d) record and monitor the results as evidence of compliance;

(e) audit the quality assurance processes and procedures to ensure compliance; and

(f) ensure that prompt action is taken to correct noncompliance.

The quality assurance plan shall comply with the principles of ISO9001. It shall clearly describe the systems, procedures and methods that will be used to deliver and monitor compliance of the Services.

\section{Health and Safety Management Plan}

The purpose of the health and safety management plan is to foster a responsible attitude towards occupational health and safety and to comply with the provisions of local laws.

Because of the nature of the services, the contractor may occasionally be exposed to hazardous situations, which could involve risk of various degrees of harm, to the contractor's personnel and/or the public.

Situations will arise when it is not practical to eliminate or isolate significant hazards. In these situations, the contractor must mitigate hazards by ensuring planned 
protection systems (e.g., equipment, clothing) are available and used. The contractor's personnel and all sub-contractors must comply with the health and safety management plan at all times.

The health and safety management plan shall, when implemented in accordance with the plan requirements:

- ensure the systematic identification of existing and new hazards on work site(s) and at depots, storage facilities, in offices or wherever activities are undertaken;

- ensure the mitigation of significant hazards, where elimination and isolation are impractical;

- ensure the provision and use of appropriate protective measures;

- include emergency procedures for dealing with accidental spillage, pollution or imminent danger;

- ensure regular review and assessment of each hazard identified and monitor employees exposure to these hazards;

- ensure reporting and recording of work site safety incidents so health and safety problems can be addressed quickly and regularly. It is a requirement of this contract that any such incident be advised promptly to the project manager; and

- comply with all other health and safety aspects requirements of local laws and regulations.

\section{Environmental Management Plan}

The purpose of the environmental management plan is to foster a responsible attitude toward occupational health and safety and to comply with the provisions of the local laws. The environmental management plan shall comply with the principles of ISO 14001. ${ }^{2}$

Because of the nature of the services, the contractor's operations have the potential to cause adverse environmental impacts. Situations will arise when it is not practical to avoid such impacts. In these situations, the impacts must be mitigated by planned actions and protection measures, which must be employed.
The contractor's personnel and all sub-contractors shall comply with the environmental management plan at all times.

The environmental management plan shall, when implemented in accordance with the plan requirements:

- set out a clear and coherent environmental management policy of the contractor;

- describe the overall environmental management system of the contractor;

- ensure the systematic identification of potential environmental impacts associated with the contractor's operations and/or the use of the roads;

- ensure the mitigation of significant environmental impacts, where elimination and isolation are both impractical;

- ensure the provision and use of appropriate protective measures;

- include emergency procedures for dealing with accidental spillage, pollution or imminent danger;

- ensure regular review and assessment of each impact identified and monitor effectiveness of mitigation or protection measures;

- ensure reporting and recording of significant incidents causing environmental impacts so that problems can be addressed quickly and regularly. It is a requirement of this contract that any such incident be advised promptly to the project manager; and

- comply with all other environmental protection requirements of the relevant law and regulations.

\section{Risk Management Plan}

The purpose of the risk management plan is to ensure that uncertain events that may have adverse impacts on the integrity and condition of the road assets or on the operational service levels are identified, analyzed and placed under a proactive management regime. The risk management plan shall, as a minimum, include:

ISO 14001:2004 specifies requirements for an environmental management system to enable an organization to develop and implement a policy and objectives that take into account legal requirements and other requirements to which the organization subscribes, and information about significant environmental aspects. It applies to those environmental aspects that the organization identifies as those which it can control and those it can influence. 
- establishment of a risk register, in which all foreseeable adverse events are identified and assigned values of probability and consequence of occurrence;

- analysis of risks in which the impact of potential combinations of events is considered across a range of scenarios;

- identification of risk management strategies involving avoidance and mitigation of risks together with management strategies for residual risks;

- assignment of responsibility for risks to the organizations or individuals best able to manage them; and

- a process for the regular review and updating of the risk register and the risk management plan.

\section{Emergency Procedures and Contingency Plan}

The emergency procedures and contingency plan shall establish the roles, practices, and procedures to be followed during and following the occurrence of natural phenomena with unforeseen consequences, such as strong storms, flooding and earthquakes. The emergency procedures and contingency plan shall be developed by the contractor and agreed with the project manager and any other stakeholders the project manager may identify.

The purpose of the emergency procedures and contingency plan is to ensure the safety of the contractor's personnel and road users in the case of emergency and/or road closure. It should include:

- an effective communication and event recording system;

- the names, 24-hour contact telephone numbers and specific duties of the contractor's personnel nominated to respond to an emergency event;

- the contact telephone numbers of other parties who need to be notified in cases of emergency events, e.g., police;

- detailed response procedures for all potential emergency events; and
- possible detour routes in the event of road closure.

\section{Traffic Management Plan}

The traffic management plan establishes the practices for traffic management at work sites and shall comply with the relevant local rules and regulations. The traffic management plan must be developed by the contractor and agreed with the project manager. The objectives of the traffic management plan are to

- clearly define and document the responsibilities and chain of command for the development, implementation and management of traffic control measures and systems;

- establish the minimum requirements for temporary traffic control;

- establish the minimum geometric, cross section and surfacing standards for temporary works;

- provide appropriate transitions and enable safe and efficient traffic flow into, through, and out of work sites;

- protect the contractor's personnel at all times;

- protect the road and related assets and the contractor's resources at all times; and

- meet the operational requirements for the road.

The traffic management plan must include at least the following:

- a documented process for preparation, review and approval of the traffic management plan;

- a document tracking and control system to ensure that only the latest operative copy of the traffic management plan is in circulation;

- 24-hour contact telephone numbers for contractor, project manager, emergency services and other stakeholders; and

- layout diagrams, method statements, etc. for implementation of traffic control while undertaking each aspect of the services (including site specific layout diagrams and method statements if the services require traffic control measures not covered by standard codes of practice). 


\section{Data Collection}

\section{and Management Plan}

The information management plan establishes the practices for collection, storage, analysis and reporting of data and information required for the administration and management of the works and services. The information management plan shall be developed by the contractor and agreed with the project manager.
The contractor shall prepare a data collection plan, which shall describe the methods and frequency of data collection together with the approach to be taken to quality assurance and quality control of data.

The contractor shall collect the data in accordance with the data collection plan at the levels of accuracy, currency and completeness specified as appropriate to the uses for which the data is intended. 



\title{
Guide to Performance-Based Road Maintenance Contracts
}

Road asset management is one of the top priorities of the Central Asia Regional Economic Cooperation (CAREC) Transport and Trade Facilitation Strategy 2020. The implementation of performance-based road maintenance contracts (PBCs) - an essential element of road asset management-promotes effective and efficient maintenance of road networks. Well-designed PBCs keep roads in predefined good condition at relatively low cost. This guide aims to help policy makers in CAREC member countries understand and implement PBCs. After a brief history of the development of PBCs, it discusses the various types of PBCs and their relative advantages and disadvantages. It highlights PBC implementation in selected developed, developing, and transitional countries, including CAREC member countries, to illustrate best practices.

\section{About the Central Asia Regional Economic Cooperation Program}

The Central Asia Regional Economic Cooperation (CAREC) Program is a partnership of 11 member countries and development partners working together to promote development through cooperation, leading to accelerated economic growth and poverty reduction. It is guided by the overarching vision of "Good Neighbors, Good Partners, and Good Prospects." CAREC countries include: Afghanistan, Azerbaijan, the People's Republic of China, Georgia, Kazakhstan, the Kyrgyz Republic, Mongolia, Pakistan, Tajikistan, Turkmenistan, and Uzbekistan.

\section{About the Asian Development Bank}

ADB's vision is an Asia and Pacific region free of poverty. Its mission is to help its developing member countries reduce poverty and improve the quality of life of their people. Despite the region's many successes, it remains home to a large share of the world's poor. ADB is committed to reducing poverty through inclusive economic growth, environmentally sustainable growth, and regional integration.

Based in Manila, ADB is owned by 67 members, including 48 from the region. Its main instruments for helping its developing member countries are policy dialogue, loans, equity investments, guarantees, grants, and technical assistance.

$\mathrm{ADB}$

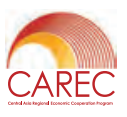

CAREC SECRETARIAT

WWW.carecprogram.org 